\title{
UN NUEVO ENCLAVE FENICIO DESCUBIERTO EN LA BAHÍA DE CÁDIZ: EL CERRO DEL CASTILLO, CHICLANA
}

\author{
A NEW PHOENICIAN LOCATION DISCOVERED IN THE BAY \\ OF CADIZ: EL CERRO DEL CASTILLO, CHICLANA
}

\author{
PALOMA BUENO SERRANO* \\ JUAN A. CERPA NIÑO**
}

Resumen: Los recientes hallazgos arqueológicos en el casco antiguo de Chiclana han aportado nuevos datos sobre la colonización fenicia en la bahía de Cádiz. El importante descubrimiento de un recinto fortificado, correspondiente al primer momento de la misma y de la creación de factorías en contexto peninsular, supone un avance significativo para el conocimiento de la organización territorial del momento y una nueva fuente de datos para la investigación arqueológica e histórica actual. El hecho de que ahora sean tres los enclaves fenicios existentes en la bahía: Cádiz, Chiclana y Doña Blanca (El Puerto de Santa María), permite una mejor interpretación de los textos griegos, que denominaban a esta zona Gadeira y al templo de Melkart, en Chiclana "puerta de Occidente".

Palabras clave: Colonización, fenicios, Bronce Final, recinto fortificado, factorías, Hierro I

\section{UBICACIÓN}

El término municipal de Chiclana de la Frontera, situado en la costa atlántica de Cádiz, se encuentra situado entre el litoral y la campiña, con escaso relieve sin llegar a superar los $200 \mathrm{~m}$. Su zona más montañosa se encuentra al Este, próxima a Medina Sidonia, en la cuenca del río Iro donde se ubican las estribaciones de la Loma del Lentiscar. Toda su campiña está compuesta

\footnotetext{
* Arqueóloga. Universidad de Cádiz.

** Arqueólogo. Empresa de Arqueología y Restauración.
}

\begin{abstract}
The recent archeological findings in old uptown Chiclana have contributed new data about the Phoenician settlements in the Cádiz Bay. The important discovery of a fortified enclosure, in snchrony with the first Phoenician colonization and also with the creation of factories within the peninsular context, constitutes a significant advance in the present archaeological and historiacal research. The fact that we now have there Phoenician settlements in the Bay area, Cádiz, Chiclana and Doña Blanca, allows us a more accurate interpretation of the Greek text wich refered to this location as Gadeira and to the Melkart temple as the "gate to the West".
\end{abstract}

Key words: Colonization, phoenicians, Bronze Final, fortified, factories, Iron I

por un paisaje abierto con elevaciones suaves que no superan los 40 m s.n.m. (Fig. 1).

$\mathrm{Su}$ formación geológica se manifiesta de forma variada. En la zona occidental destacan las marismas formadas por arenas y arcillas que se originaron en el Holoceno. En el centro se hallan las arenas amarillas y biocalcarenitas (facies de roca ostionera) de origen Plioceno entremezcladas con áreas de arenas y cantos (glacis de cobertura) enmarcados en el Pleistoceno Inferior y Medio. Arcillas, yesos y areniscas del Trías ocupan la zona Oeste, donde abundan rocas básicas muy útiles para elaborar elementos de uso pulimentados en época prehistórica. 


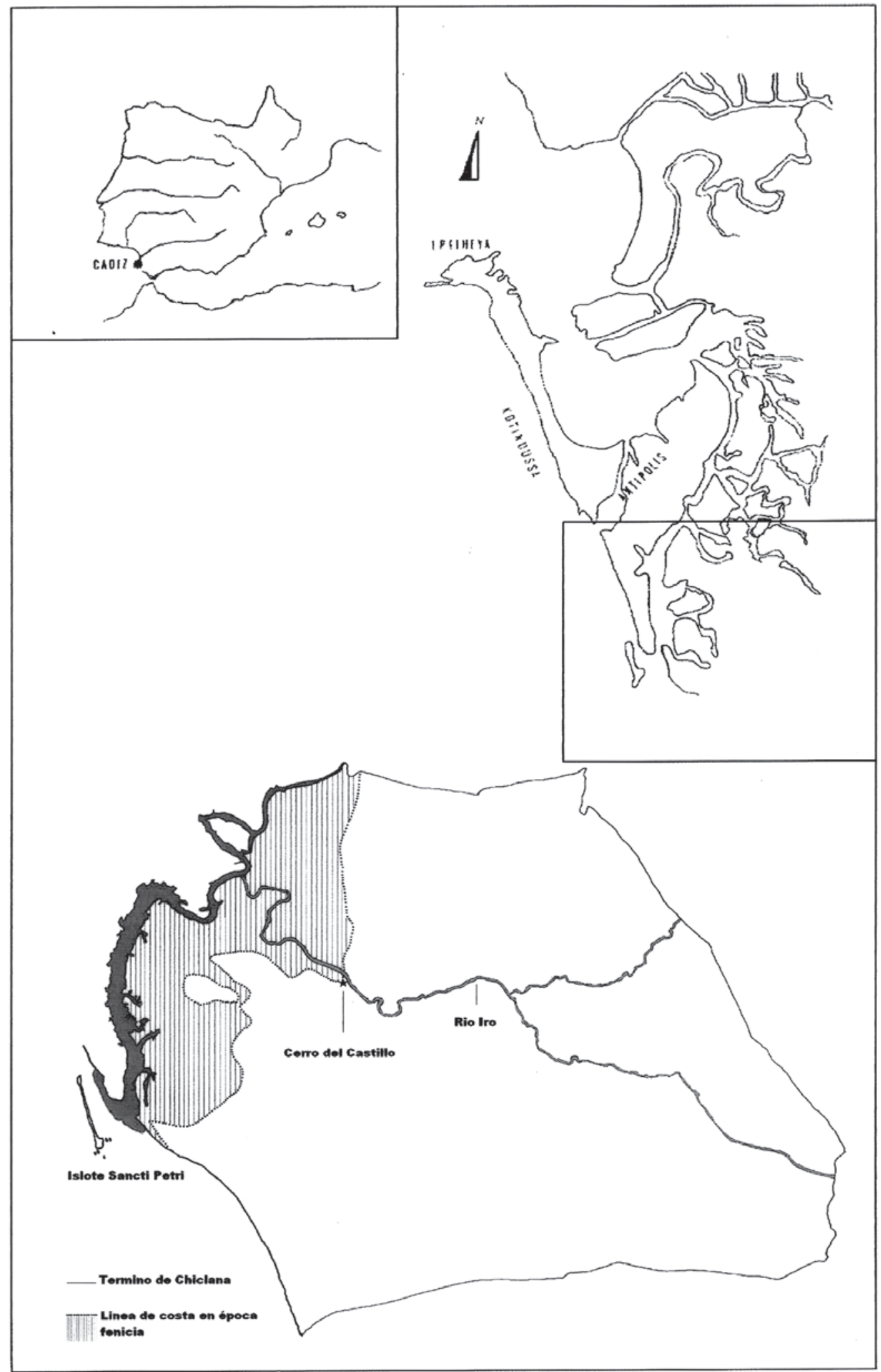

Figura 1.- Situación de Chiclana de la Frontera en la Provincia de Cádiz y en la península ibérica 


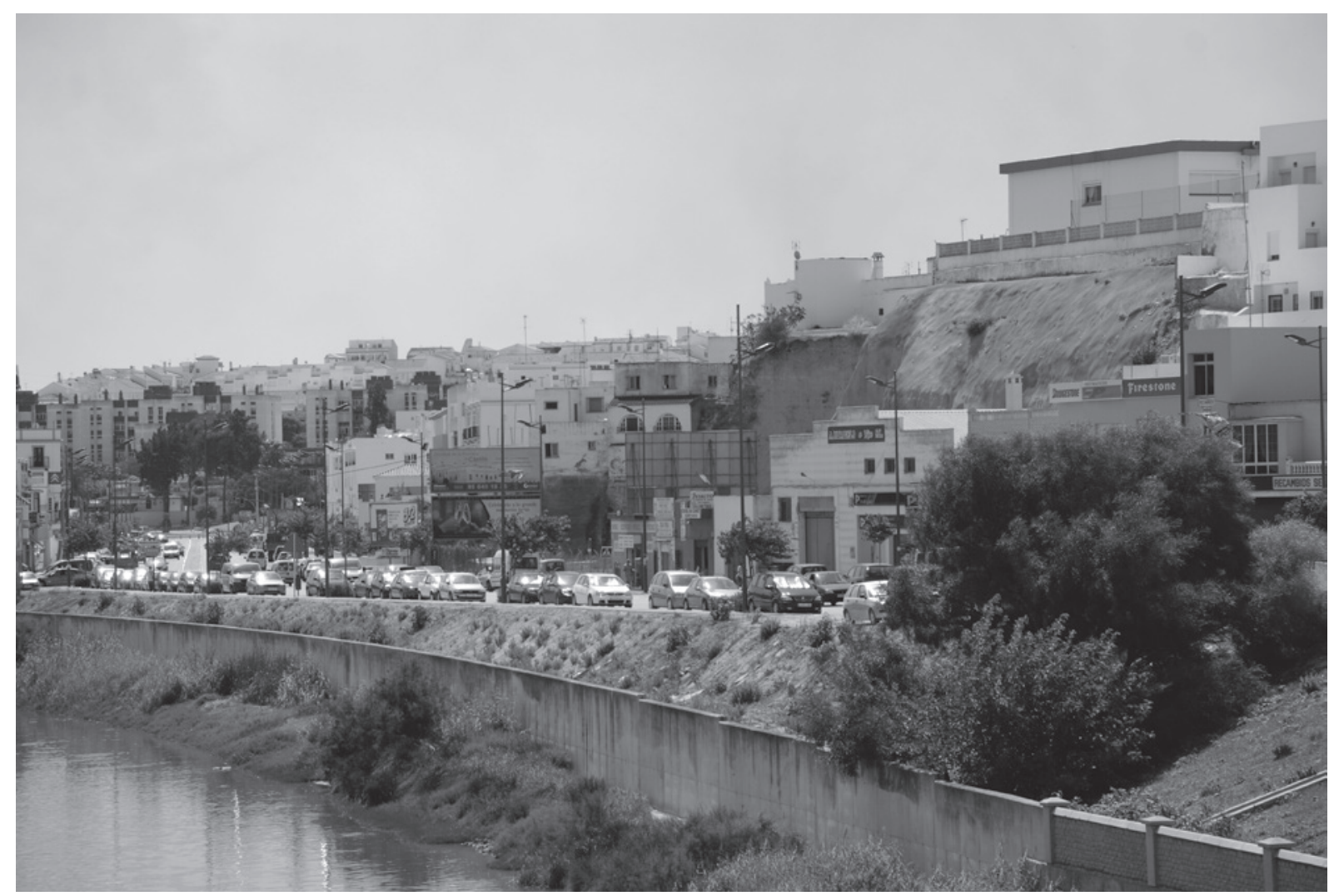

Lámina I. Vista general del Cerro del Castillo y del río Iro (Chiclana)

Todo este paisaje tan diverso, compuesto por un litoral atlántico, campiñas de relieves suaves, abundantes cerros, suelos ricos para la agricultura y ganadería, constituye una extraordinaria fuente de recursos para su explotación en la actualidad y también para las comunidades primitivas y colonizadoras que habitaron en él.

El núcleo urbano se halla formado por una serie de cerros o cabezos elevados entre los que destacan el Cerro del Castillo, el de Santa Ana, el Cerrillo, etc., conformando un paisaje que se asemeja a otros enclaves tartésicos como el caso de Huelva o la costa malagueña. Entre todos ellos destaca el Cerro del Castillo, cargado de historia, como han demostrado recientes investigaciones, y origen de la ciudad actual de Chiclana. Su situación estratégica junto al río Iro, le otorga un importante papel a la hora de ser elegido como enclave por los pueblos de todas las épocas. Su denominación proviene de la fortificación mandada construir por Alonso de Guzmán "El Bueno" en 1303, de la que aún no se conocen restos (Lám. 1).

Para situarnos en el contexto geográfico del área, definiremos el Cerro del Castillo como el lugar más elevado de la ciudad, cuya extensión se desarrolla dentro del recinto amurallado o pequeña fortificación, como hemos mencionado, desde época medieval, ocupando una superficie aproximada de 10 hectáreas. Dentro de esta reducida zona encontramos la Iglesia Mayor de San Juan Bautista (siglo XVIII) y la hoy desaparecida Iglesia de San Martín (siglo XV) en la actual calle Convento que organizan un conjunto urbano, en un tejido aglutinado con calles de pequeña longitud angostas y tortuosas, cual merece su ascendencia medieval. A sus pies y hacia el río se extendía la Huerta de la Plata que dio nombre a las calles que conducen a él: Travesía de la Plata y calle Plata. Desde la cima y en dirección E, se extiende el poblamiento por la ladera opuesta surgiendo así el denominado Barrio Nuevo.

Mucho ha cambiado el paisaje del cerro; de ser en su origen un puerto prácticamente en plena costa (Fig. 2), hoy es un lugar invadido por el entramado urbano y los sedimentos de la bahía han sustituido a las olas del mar. Se sitúa sobre una elevación natural, en un acantilado de escasa altura, junto a una pequeña ensenada que debió de servir de puerto desde sus inicios. Su proximidad al mar en la antigua costa por aquella época, justifica su elección topográfica, repitiendo los 


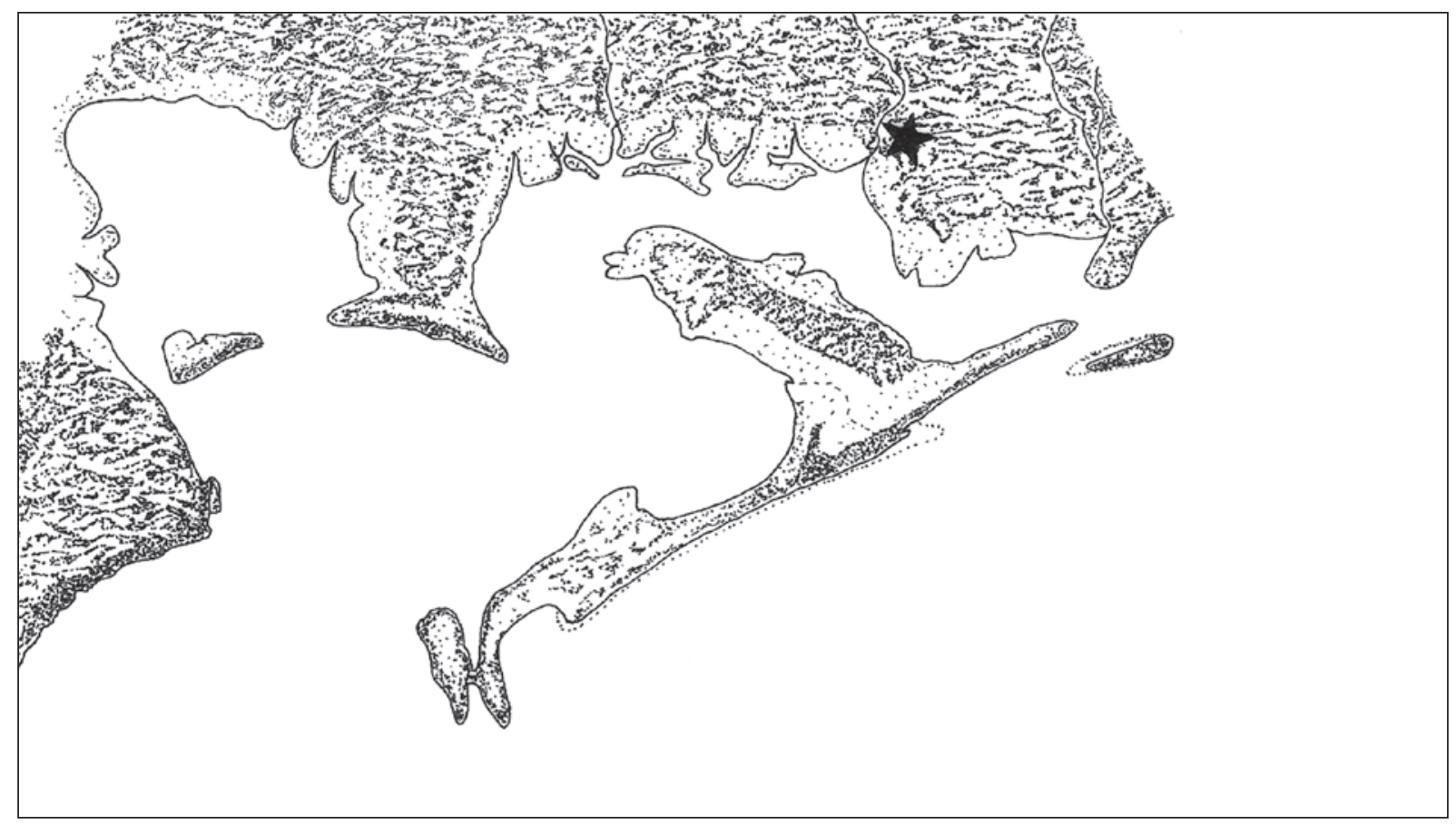

Figura 2. Plano de las antiguas islas de la bahía de Cádiz

esquemas desplegados en otros puntos de oriente y occidente. Esta zona elegida posee dominio visual hacia el mar, avistándose las islas de Cádiz y San Fernando, y hacia el noroeste Medina Sidonia y la Sierra, de modo que su elección se explica como puerto o desembarcadero, dado el carácter de zona comercial que debió tener este núcleo y la bahía en general. Por todo ello se comprende la elección tan estratégica de este enclave.

Antes de comenzar la intervención, el terreno que ocupaba el solar excavado donde aparecieron los restos arqueológicos presentaba una topografía peculiar al poseer una fuerte pendiente. Fue esta orografía tan irregular la que nos llamó poderosamente la atención y nos hizo pensar que en la zona más alta debían existir construcciones soterradas.

\section{LA EXCAVACIÓN ARQUEOLÓGICA: INICIO Y METODOLOGÍA}

Los trabajos comenzaron en septiembre de 2006 y finalizaron en abril de 2007. La metodología utilizada, en cuanto a trabajos de campo se refiere, consistió en el planteamiento de dos fases: una primera intervención con la ejecución de 12 sondeos arqueológicos y una segunda consistente en la excavación en extensión de todo el solar.
En la primera fase se plantearon los sondeos para poder obtener una serie de datos básicos en cuanto a la densidad y niveles arqueológicos, informaciones que se desconocían, composición del terreno y localización del firme natural. Las peculiaridades del solar a intervenir, aterrazado y con una pronunciada pendiente, nos llevó a la realización de los mismos de forma escalonada, comenzando desde la zona más baja hacia la cima del cerro.

La detección de materiales arqueológicos en la zona baja fue inmediata, aumentando de forma paulatina conforme se ascendía sobre las terrazas. Desestimamos profundizar en algunos de ellos por la aparición de niveles arqueológicos prácticamente en superficie. Junto a estructuras antiguas afloraban gran cantidad de fragmentos cerámicos realizados a mano, con decoración bruñida, retícula bruñida, y a torno con engobe rojo, así como estructuras murarias y diversos pavimentos que nos confirmaban la existencia de una ciudad fortificada de origen fenicio.

La segunda fase consistió en la excavación en extensión en toda la zona donde fueron detectadas estructuras murarias, pavimentos, etc. Todos estos niveles así como las estructuras estaban afectados debido a la ocupación constante del cerro en todas las épocas: desmontes de la muralla, posiblemente visible aún en época medieval, arrasamiento parcial de los depósitos y estructuras más antiguas para la realización de silos 


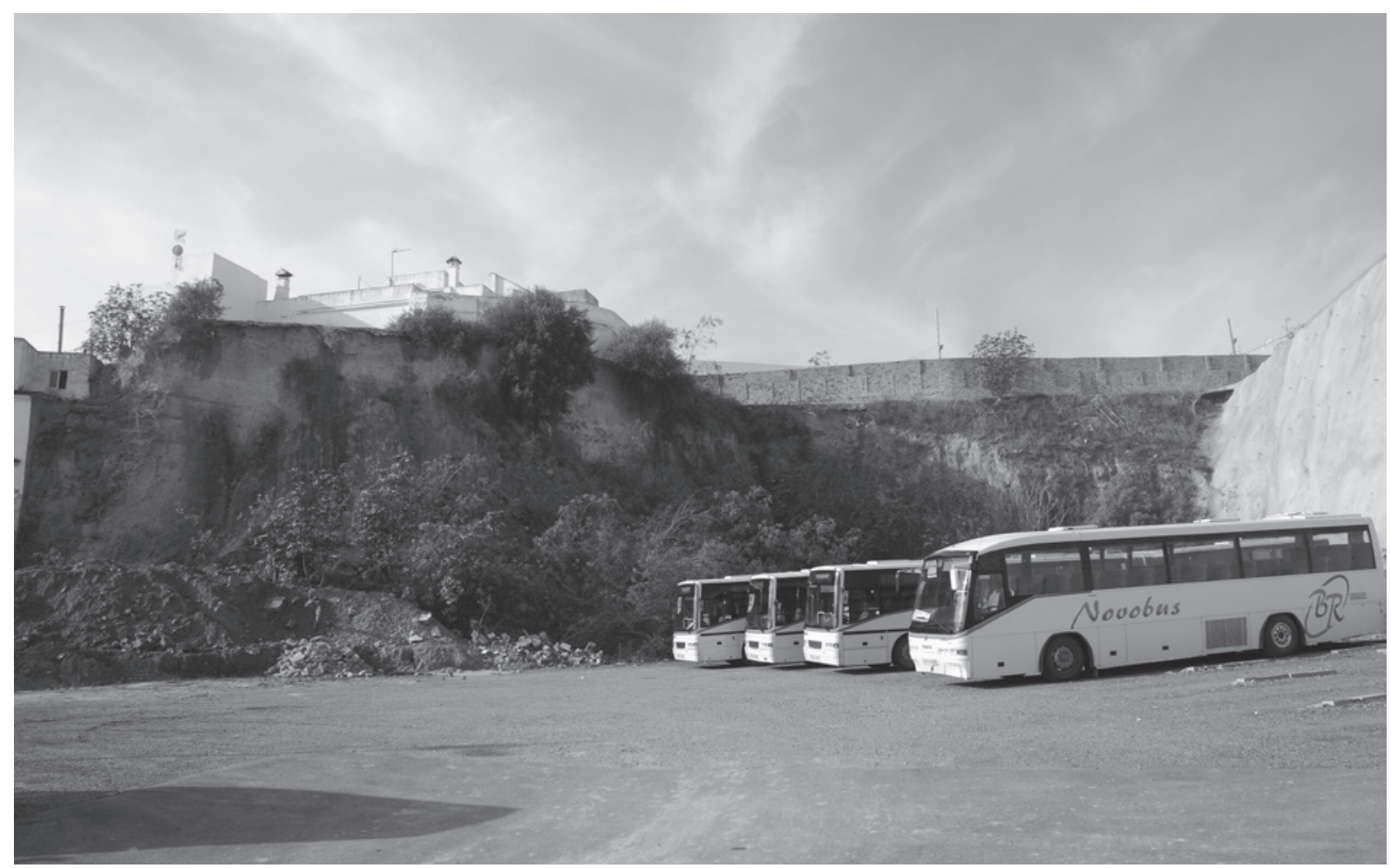

Lámina II. Vista parcial del Cerro del Castillo donde se observa la extracción de tierra realizada hace unos años y los desplomes que sufre actualmente

medievales, canalizaciones y atarjeas moderno-contemporáneas. A esto debemos añadir dos circunstancias: la primera, que toda esta zona estuvo ocupada por el cementerio de la ciudad, prácticamente en uso hasta finales del siglo XIX; y la segunda, que la existencia un subsuelo compuesto de arenas amarillas y biocalcarenitas (facies de roca ostionera) de origen Plioceno con escasa consistencia, ha originado sucesivos y continuos derrumbes de la ladera Norte (Lám. II).

Por otro lado debemos tener en cuenta que la intervención arqueológica realizada se halla incompleta ya que la falta de tiempo y las presiones del promotor impidieron finalizar el trabajo en algunas zonas concretas que nos podrían aportar datos de vital importancia en cuanto a períodos de ocupación, reformas, ampliación y otros aspectos del asentamiento.

\section{FASES DE OCUPACIÓN DURANTE EL BRONCE FINAL-HIERRO I}

Una vez concluida la excavación, podemos decir que se documenta una sucesión de etapas o periodos cronológicos.

\subsection{Primera Fase. Siglo VIII a.C.}

Podemos constatar la ocupación durante el Bronce Final del Cerro del Castillo no solo en los niveles inferiores excavados bajo los restos fenicios (Fig. 3), sino también en el sondeo realizado en el patio del C. P. El Castillo, donde, bajo los estratos romanos, se excavó parte de una estructura piriforme horadada en la base del cerro. Esta estructura contenía un repertorio cerámico realizado a mano con características formales que podrían otorgarle cierta antigüedad. Se trata de una fosa sobre el nivel geológico con forma de lengua de unos 50 cm de espesor que contiene gran cantidad de fragmentos de recipientes fechables en el Bronce Final (Fig. 4).

A un momento avanzado de esta etapa corresponde el primer asentamiento fenicio, con el recinto fortificado y las primeras habitaciones en el interior del mismo (Fig. 5). Durante esta fase, que nosotros incluimos en la Fase I-II de Ruiz Mata (1979:3) o tartésico colonial u orientalizante (Pellicer y otros 1983), es cuando se produce la convivencia entre población autóctona y fenicios (desde el 775 a.C. hasta finales del siglo VIII a.C.).

De la recia y potente muralla de casernas se han excavado 44,5 m lineales sin detectarse torres, 


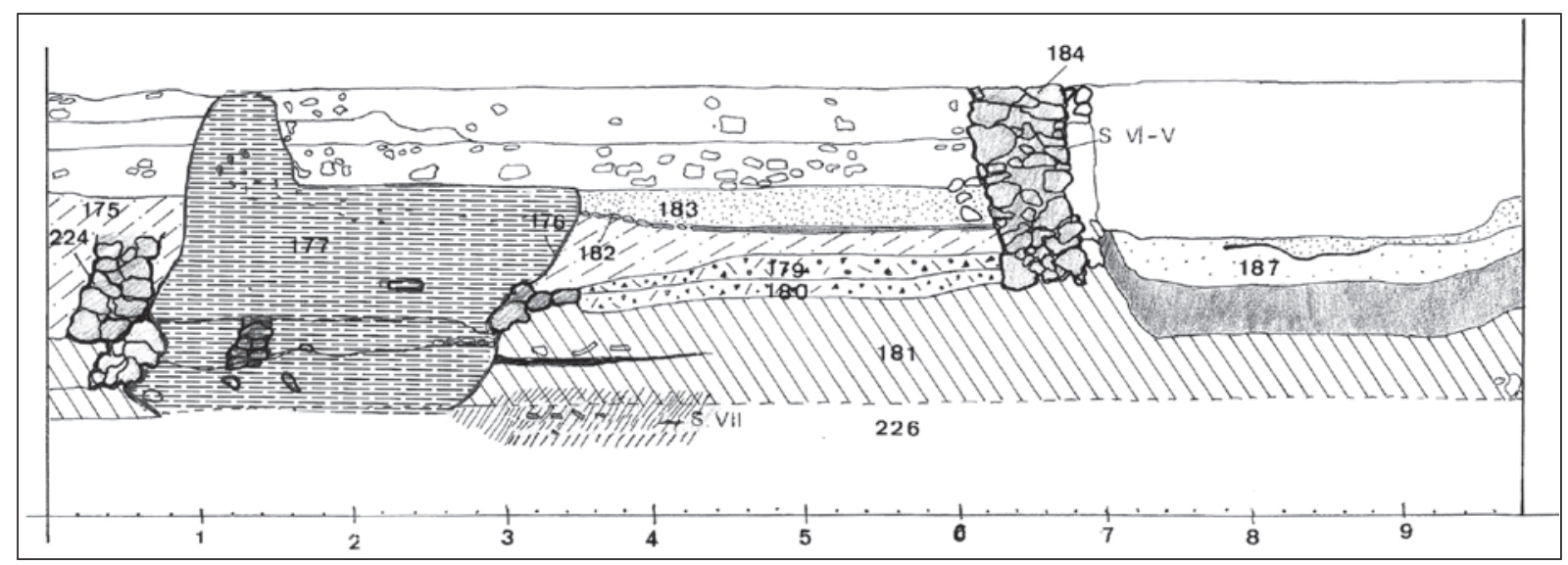

Figura 3. Estratigrafía hallada en el sector excavado del Cerro del Castillo

contrafuertes, estructuras anexas, vanos, ni pasos, al menos al nivel que se conservaba (Lám. III). Está formada por dos lienzos paralelos, el exterior, de mayor anchura (1,80 m), construido con mampuestos de gran tamaño que dan solidez y consistencia a la obra, y el interior que, aunque de una anchura menor $(1,30 \mathrm{~m})$ conserva la misma potencia de la exterior (Lám. IV). Entre ambos lienzos, separados por un espacio hueco de $80 \mathrm{~cm}$, aparecen una serie de muros transversales o tirantes $(80 \mathrm{~cm})$ que garantizan la estabilidad tanto en altura como en anchura, repartiendo de manera equitativa fuerza y peso. Estos muros forman espacios internos muy pequeños $(0,80 \mathrm{~cm} \times 2,70 \mathrm{~m})$, que fueron colmatados con un relleno uniforme de arena local que contiene ciertas inclusiones de fragmentos de cerámicas realizadas a mano.

Toda la obra se halla bien trabada con una arcilla muy depurada de color rosada y marrón colocada a pelladas entre los mampuestos. Se construyó y se asentó sobre el suelo natural preparado previamente, en el aparecen en algunas zonas niveles del Bronce Final. Adolece, al menos en la parte excavada hasta el momento, de foso defensivo, que sería innecesario si observamos la pronunciada pendiente natural que conserva el propio cerro. Aunque los vestigios detectados en solares colindantes, y de manera superficial en algunas calles adyacentes, son escasos aún y, con las reservas debidas para una interpretación planimétrica, creemos que el recinto fortificado ofrece una planta cuadrangular con una superficie aproximada entre las 9 o 10 ha (Fig. 6).

Pertenecen a este periodo una serie de muros y pavimentos de arcilla rojiza que arrancan del lienzo interior de la muralla para formar las estancias dentro del hábitat fortificado (Lám. V). Al respecto, hay que tener presente que bajo los niveles exhumados existe una secuencia estratigráfica con diferentes niveles de ocupación. Sus fases arcaica y de abandono se hallan entremezcladas debido al entramado urbano que se va produciendo con la actividad constructiva a través de los siglos, siendo dificultoso poder determinar la secuencia cultural y cronológica. Aun así, los datos obtenidos de estos primeros restos urbanos que asientan directamente sobre un nivel estéril en su mayoría, unido al análisis de las estructuras que presentan rasgos estrictamente orientales, permiten hablar de una fundación fenicia en toda regla.

El registro arqueológico más abundante procede del interior del recinto fortificado con un amplio repertorio de cerámica de engobe rojo elaborado con arcillas muy depuradas, fragmentos con decoraciones pintadas y cerámica a mano como de cazuelas, cuencos y grandes recipientes para almacenar sólidos y líquidos.

\subsection{Segunda Fase. Siglos VII y VI a.C.}

A la fase II del Bronce Final u Orientalizante (Ruiz Mata 1979) o tartésico colonial u orientalizante (Pellicer y otros 1983) corresponden las reformas y arreglos que se efectúan en la muralla. Estas reparaciones nos hablan de su utilización a lo largo del tiempo. Así mismo corresponde a esta fase la mayoría de los muros y cimentaciones excavados en el solar, así como algunos pavimentos de arcilla apisonada con nódulos de barro, precursor posiblemente del denominado opus punicum, que pudieron ser bien contextualizados por su ubicación sobre la muralla y por la cultura material recuperada sobre ellos. Aparecen también pavimentos de este tipo con la misma cronología, e incluso algo posterior (siglo VI a.C.), pero en la ladera baja del cerro, 


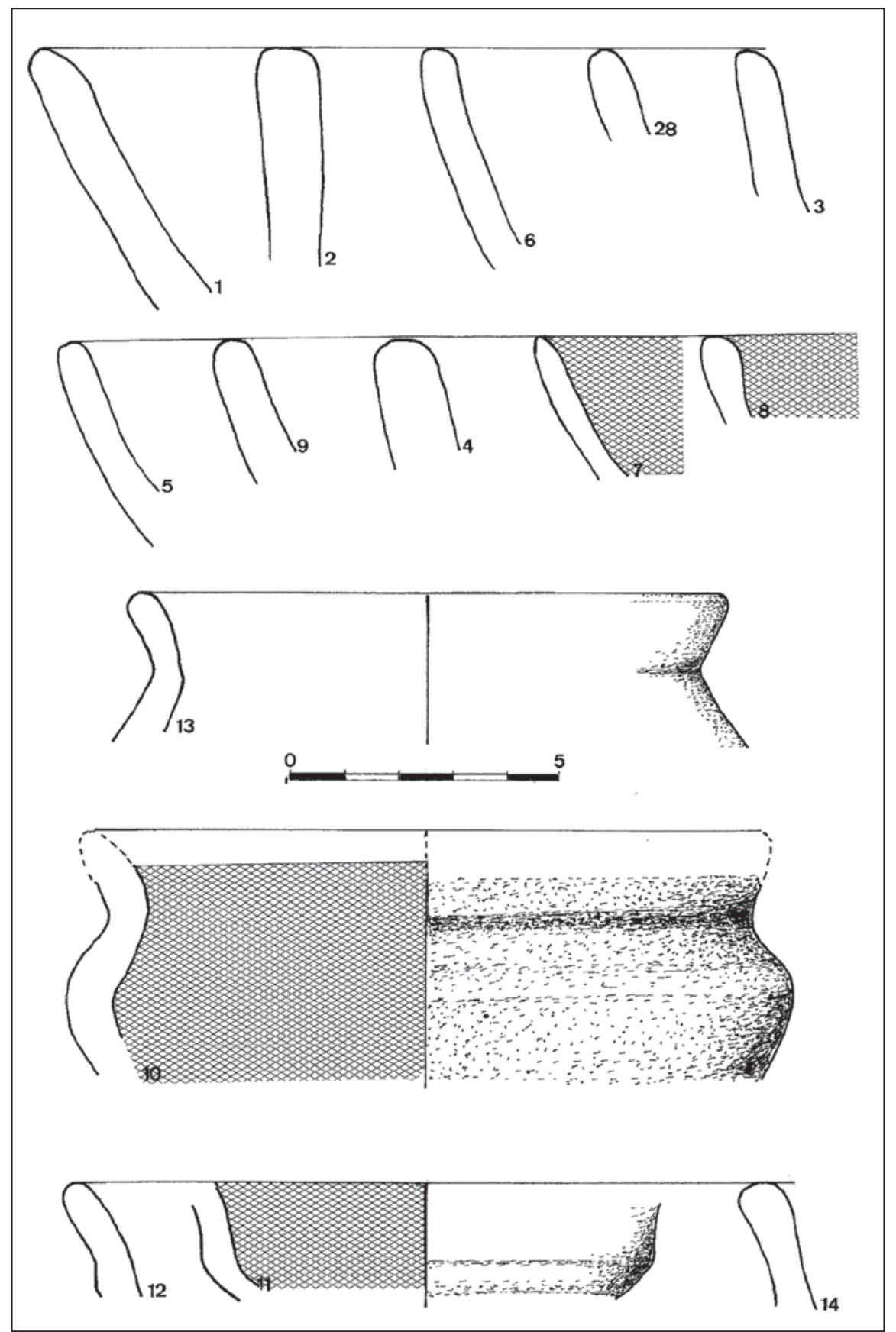

Figura 4. Material adscribible al Bronce Final hallado en el sondeo realizado en el patio del Colegio Público El Castillo

próximo al solar de la calle Convento $\mathrm{n}^{\circ} 2$, donde en fechas más recientes excavamos niveles antrópicos atribuibles al siglo VI a.C. y un horno doméstico muy mal conservado del que sólo quedaba el fondo (Cerpa y Bueno 2006). El repertorio cerámico adscribible a estos siglos es abundante y evidencia la existencia de estructuras habitacionales formando parte de una ciudad mayor aún, en un momento donde el perímetro abarcado por la muralla ha quedado superado por las construcciones. Otros muros identificados como construcciones 


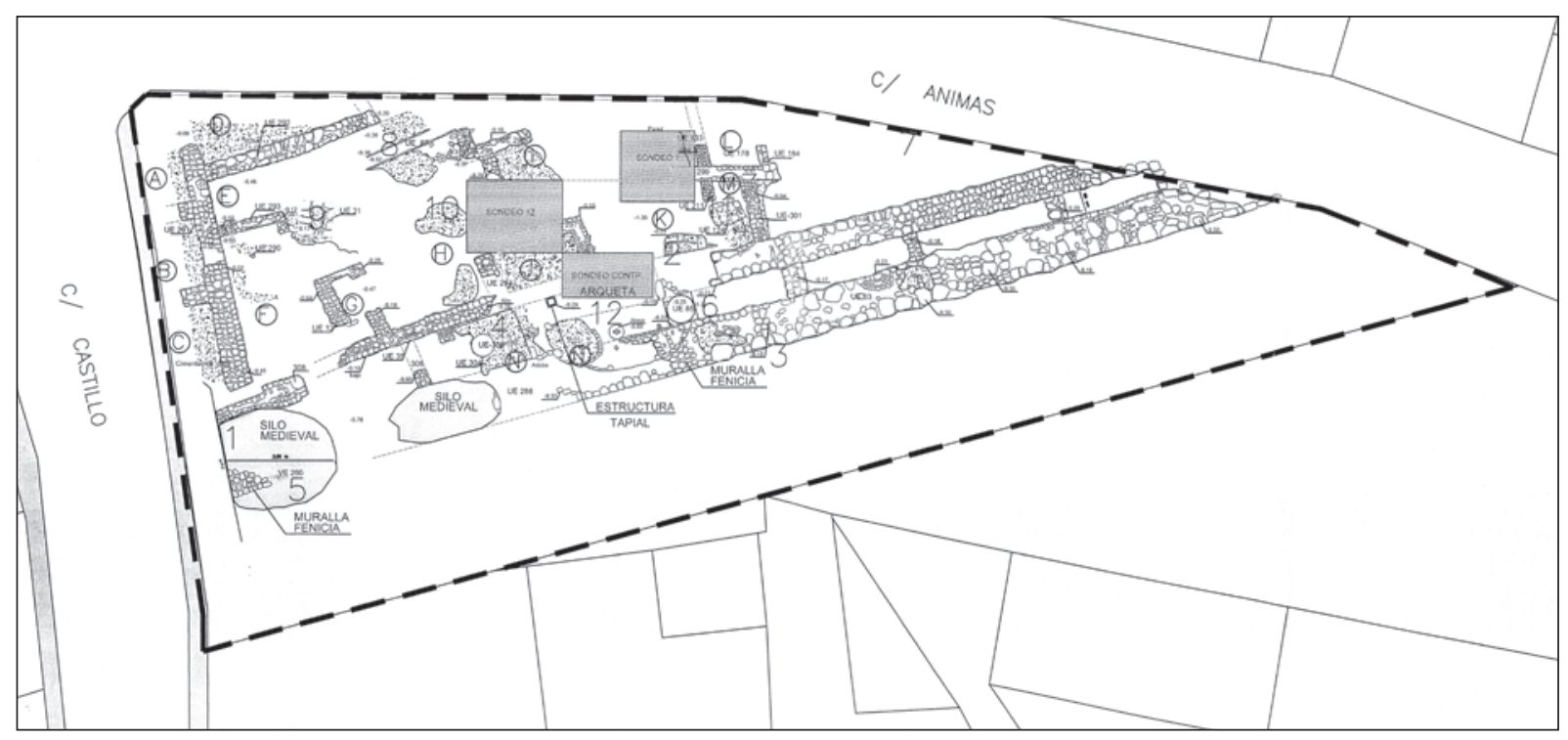

Figura 5. Dibujo en planta de los restos arqueológicos hallados

de esta época han sido hallados en excavaciones realizadas recientemente (2008) por otros colegas, en la calle Francisco Ignacio $n^{\circ} 2$, que localizamos nosotros, de manera hipotética, fuera del recinto amurallado, siguiendo nuestra teoría de que posiblemente el trazado de la muralla se corresponda con algunos peraltes observados en las calles del Cerro del Castillo.

\section{ESTUDIO DE MATERIALES}

El estudio de materiales que se presenta a continuación corresponde al análisis de todos aquellos hallados en el interior de las dependencias que sellan la ocupación en este sector del yacimiento. De los niveles inferiores, los materiales extraídos han sido escasos, debido a los pocos metros cuadrados excavados.

\subsection{Materiales adscribibles al Bronce Final}

Industria lítica

Entre los distintos depósitos antrópicos se han recogido diversas piezas líticas asociadas a materiales cerámicos de diferente cronología (a mano, autóctona y a torno, fenicia). Esta situación se produce por la escasa colmatación a lo largo de los siglos, que ha motivado una alteración estratigráfica de estos materiales residuales produciendo una mezcla y contaminación entre los distintos niveles difícilmente detectable. Así pues existen diversas formas microlaminares, pequeñas lascas de restos de talla, restos de descortezamiento de núcleos y núcleos en los que se observa la huella de extracción de pequeños cuchillos. Todas estas piezas son de sílex. Aparece también un fragmento de molino abarquillado de piedra ostionera.

Que la industria lítica pervive en época fenicia ha sido comprobado ya en otros yacimientos, por eso no constituye un dato para sostener la ocupación prehistórica del cerro. Pero la importante tradición del poblamiento desde fechas muy remotas en Chiclana, así como el hallazgo de industrias líticas pulimentadas (hachas) en la calle Convento ${ }^{\circ} 11-13$ y en Santísima Trinidad s/n, sí nos sugieren una ocupación temprana del mismo (Lám. VI).

\section{Cerámica a mano}

Es razonable la aparición de un repertorio cerámico propio de la cultura autóctona del Bronce Final en el yacimiento. La colonización fenicia en esta zona atlántica incidió sobre un hábitat de ocupación local, como demuestra el registro arqueológico, así como un comportamiento fenicio cuyo fin fue la absorción, asimilación y convivencia que trajo como consecuencia una mayor integración de la población autóctona. Es posible que en los primeros contactos y durante la construcción del recinto dicha población se hallara dispersa por 
Lámina III. Vista en primer plano de la muralla de casernas

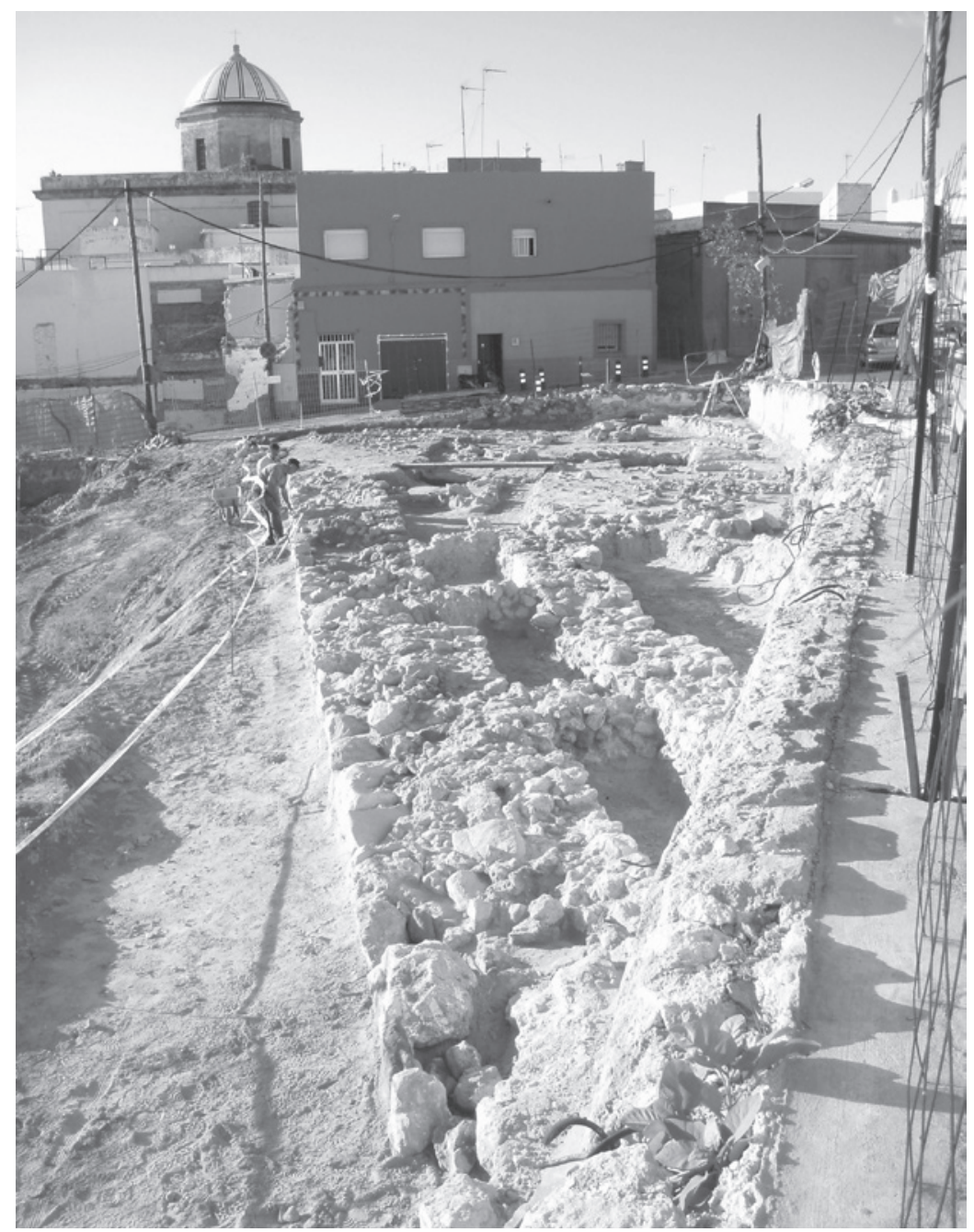

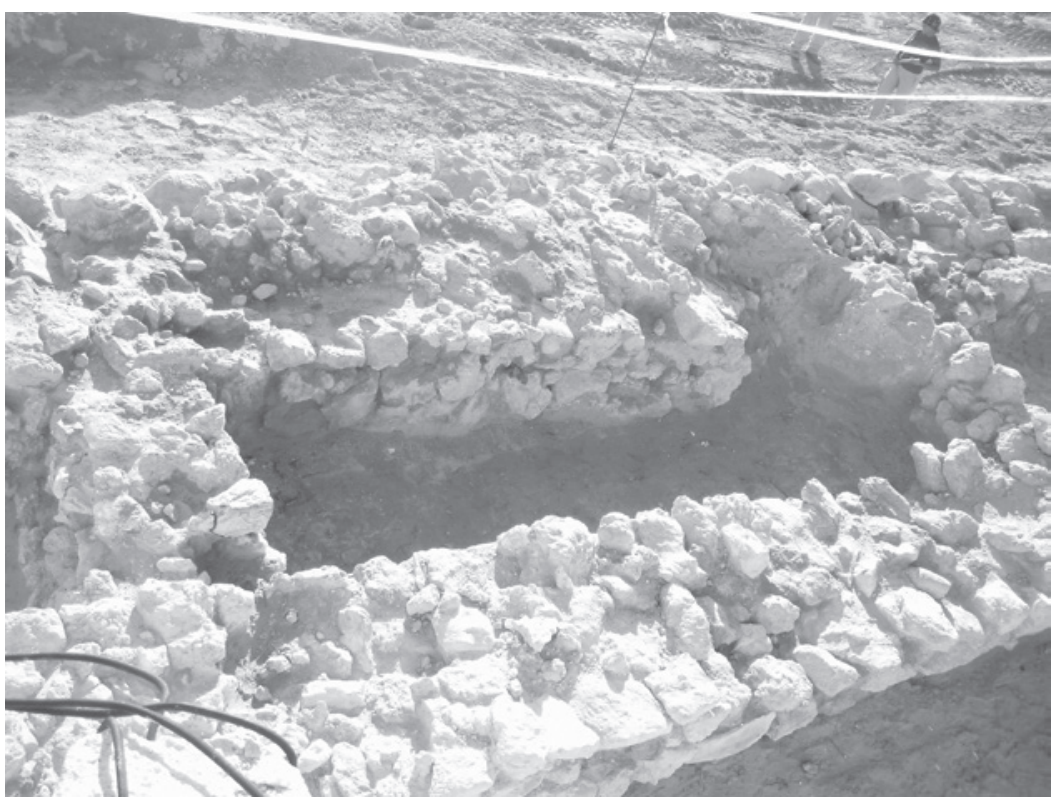

Lámina IV. Detalle de la muralla donde se aprecia que está formada por dos lienzos paralelos y tirantes 


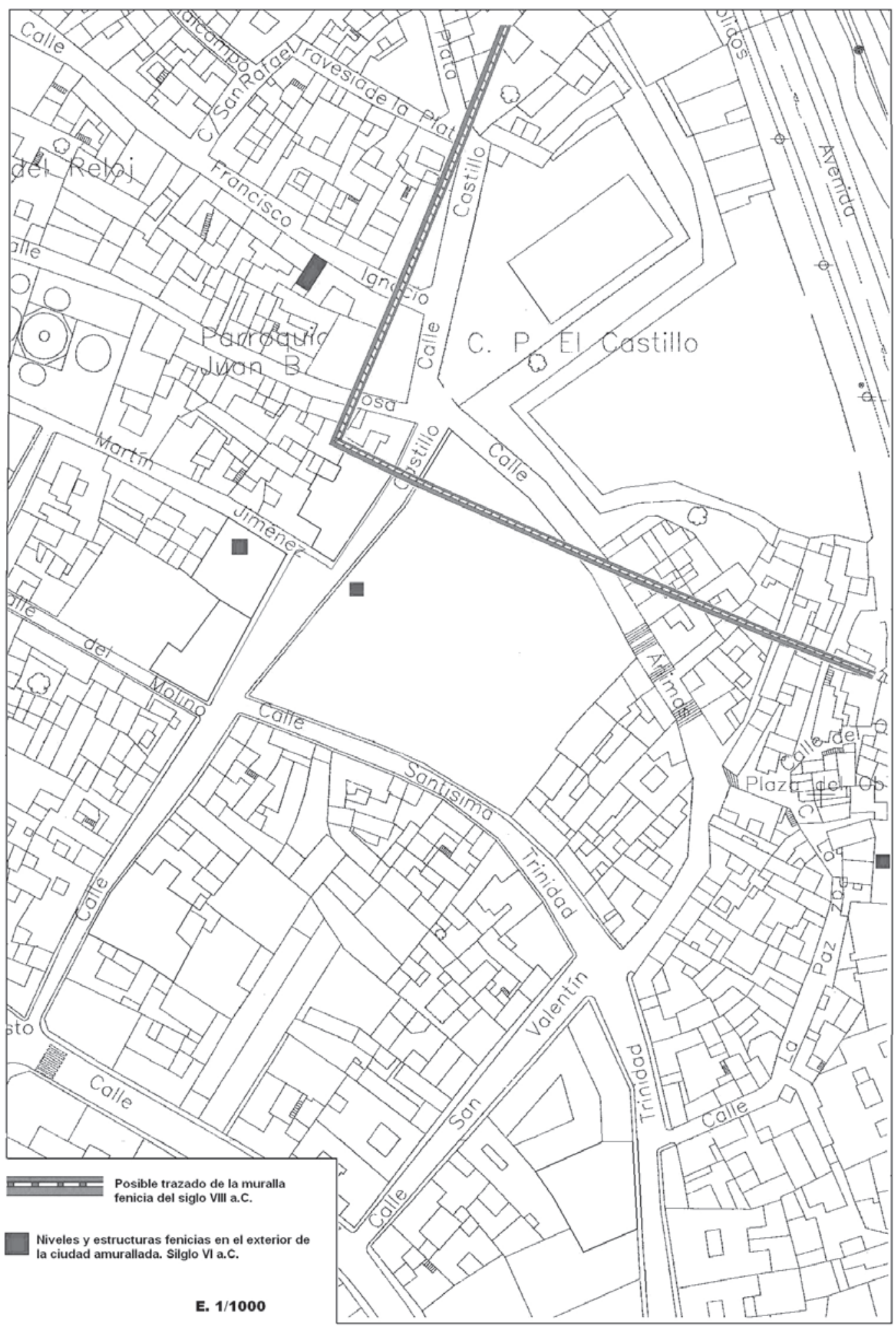

Figura 6. Posible trazado de la muralla en el Cerro del Castillo 


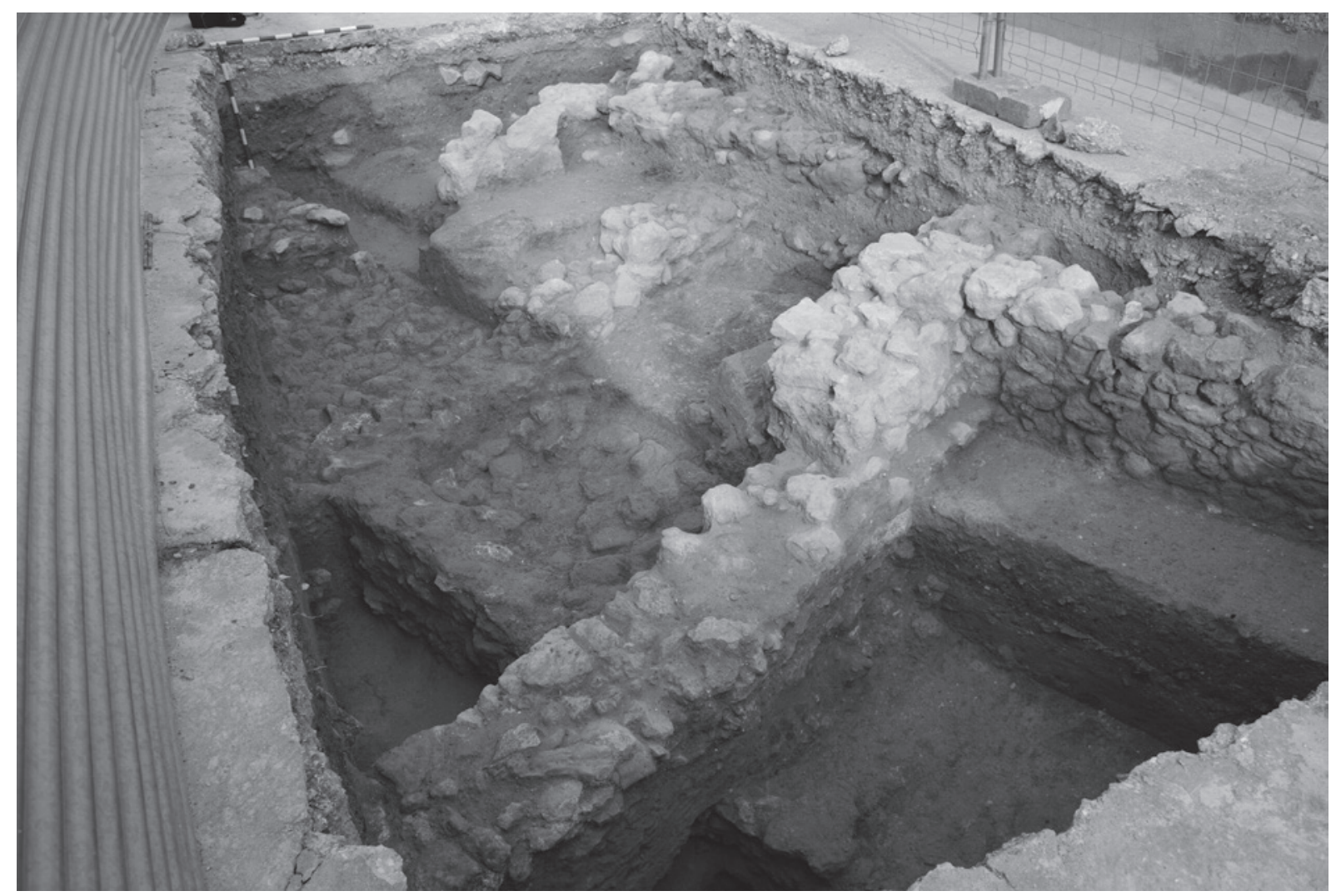

Lámina V. Detalle de la muralla en la C/. Ánimas, donde se puede observar la superposición de muros y los pavimentos de arcilla roja

los distintos cerros, y que ésta fuese acogida en la nueva ciudad como resultado de una convivencia pacífica, haciendo frente a la necesidad de una mano de obra de reducido coste.

Como hemos comentado con anterioridad, el material cerámico realizado a mano presente en el sector excavado del yacimiento corresponde a cuencos, cazuelas, copas y grandes recipientes para el almacenaje de líquidos y sólidos (Lám. VII). Entre las formas abiertas la más simple corresponde a los cuencos hemisféricos de mediano y pequeño tamaño. Éstos generalmente suelen corresponder a dos tipos; por un lado, hay fragmentos de cuencos que tienen un borde engrosado al interior, y por otro, los hay con borde simple, es decir, que las paredes del vaso tienen el mismo grosor. Esta forma tiene paralelos en toda la campiña gaditana (González Rodríguez y otros 1993; Bueno Serrano 1998), en el cercano poblado de prefenicio de Las Cumbres, datados en los siglos X-IX a.C. (Ruiz Mata y Pérez 1995:79), y en la Fase IIC de San Pedro, cuya cronología se sitúa aproximadamente en torno al 650/625 a.C. (Blázquez y otros 1979: 91, Fig. 37). En cuanto al tratamiento que reciben las superficies podemos decir que es variado: los hay con superficie exterior peinada y superficie interior alisada, bruñidos por ambas caras, bruñidos solo por la cara exterior y con decoración de retícula bruñida por el interior. El barro, cocido a baja temperatura, presenta tonalidades marrones y negruzcas, a veces con desgrasantes gruesos y medianos.

Aparecen también en este sector del yacimiento fragmentos de cuencos carenados, denominados en el Bajo Guadalquivir "cazuelas" y en Sureste peninsular y Levante "platos" o "fuentes" (Fig. 7). Los hay que presentan una carena fuertemente marcada, pero también, aparecen algunos que presentan una suave carena (Fig. 7: 4; Fig. 8: 1 y 2; Fig. 9: 1-4). En cuanto

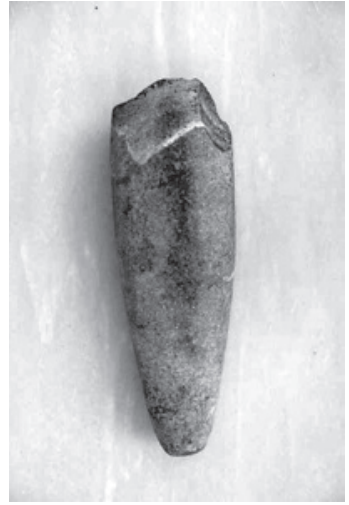

Lámina VI.

Hacha pulimentada 


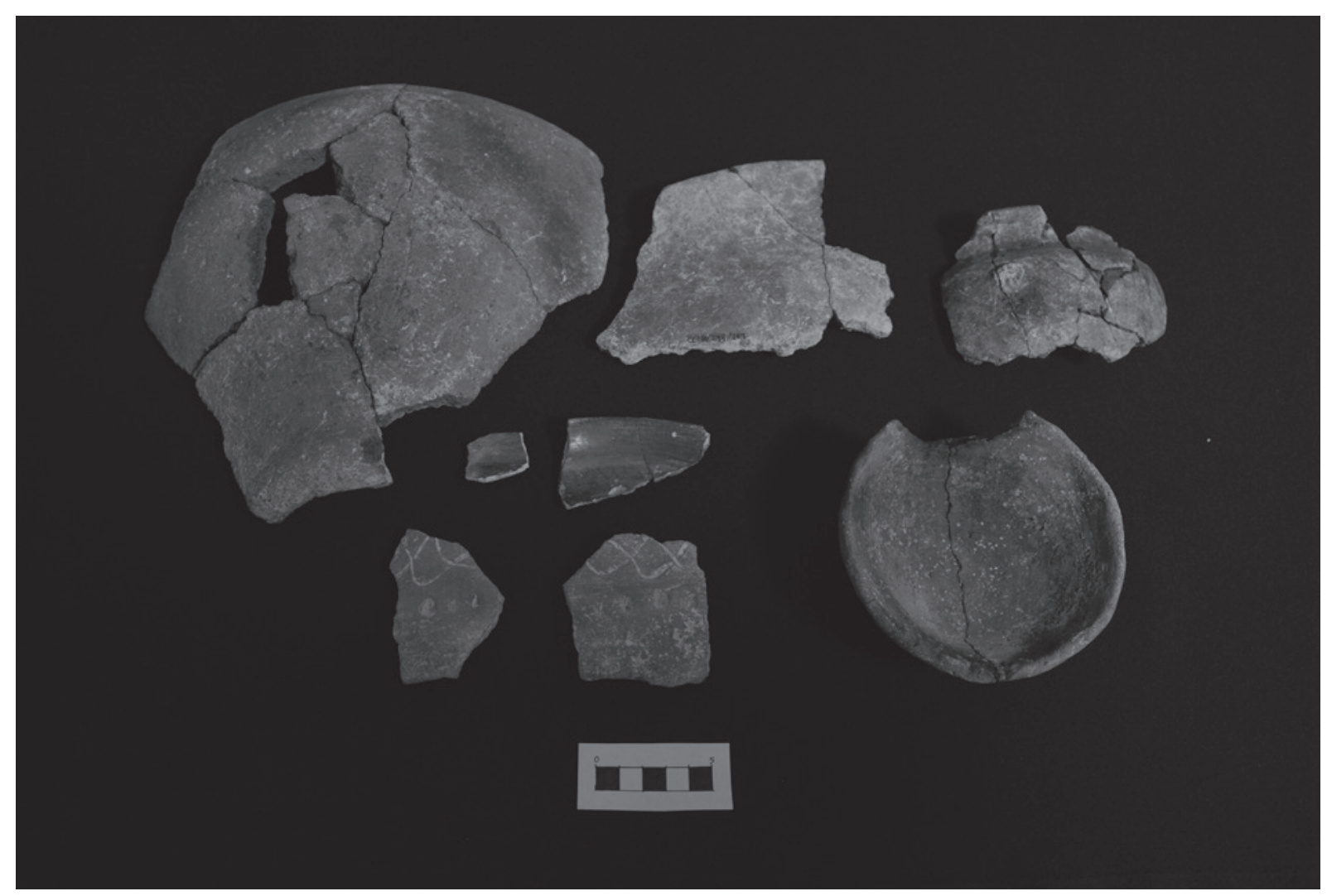

Lámina VII. Cerámica realizada a mano del Bronce Final-Hierro I

al tratamiento de las superficies, podemos decir,que algunos ejemplares presentan ambas bruñidas, consiguiendo dar al recipiente un aspecto casi metálico; los hay también que combinan varias técnicas decorativas por la superficie exterior, es decir, el borde aparece bruñido, mientras que desde la carena hacia abajo aparece peinado, o la superficie interior ha sido bruñida en su totalidad. Otros recipientes aparecen bruñidos por el exterior y por el interior, presentan el borde bruñido y el resto decorado con retícula bruñida. Esta retícula presenta motivos lineales que se entrecruzan formando rectángulos, rombos y motivos triangulares enmarcados por anchas bandas bruñidas. Las pastas cerámicas suelen presentar tonalidades negruzcas, aunque a veces también las hay marrones.

Dentro de todo el repertorio realizado a mano se hallan también los cuencos carenados o copas de reducidas dimensiones, gran calidad de factura y ambas superficies bruñidas. Similares aparecen en el poblado del Bronce Final prefenicio de Las Cumbres (Ruiz Mata y Pérez 1995: 79) y en la campiña gaditana en los yacimientos de Villarana, Cortijo de Santos Reyes, Camping Bajo, Pocito Chico, Pastranilla y Casa de Rocío
(Bueno Serrano 1998). Se registran también pequeños vasos bicónicos, con el borde corto, casi vertical (Fig. 9: 5). El tratamiento es el mismo que hemos señalado anteriormente, presentando ambas superficies bruñidas. Corresponden al Tipo B. I de Ruiz Mata (1995: 169) y se las denomina funcionalmente copas. Son frecuentes en los yacimientos del Bronce Final de Andalucía Occidental y especialmente en el Bajo Guadalquivir y en Huelva, con unas cronologías que abarcan desde el siglo VIII hasta el VII a.C. (Ruiz Mata y Pérez 1995: 276). Se trata de una de las formas que se atribuyen a una tradición anterior, al Bronce Final prefenicio.

Entre las cerámicas de superficies toscas están presentes las ollas de cocina de pastas poco depuradas decoradas con impresiones digitadas (Fig. 10). Pertenecen al Tipo G.II.a.1.a de la clasificación de Ruiz Mata (1995: 297) y a forma I de Ladrón de Guevara (1994: 4 y 45-47). También aparecen decoraciones similares sobre algunos vasos de los Fondos XIV, XXI, I.1, XI, VIII, II, 1.2 de San Bartolomé de Almonte (Huelva), fechados en la $2^{\mathrm{a}}$ mitad del siglo VIII a.C. (Ruiz Mata y Fernández Jurado 1986). Estas cerámicas se reparten por todo el territorio tartésico, acompañando la 
Figura 7. Material arqueológico realizado a mano del Bronce Final-Hierro I: Cuencos carenados o cazuelas

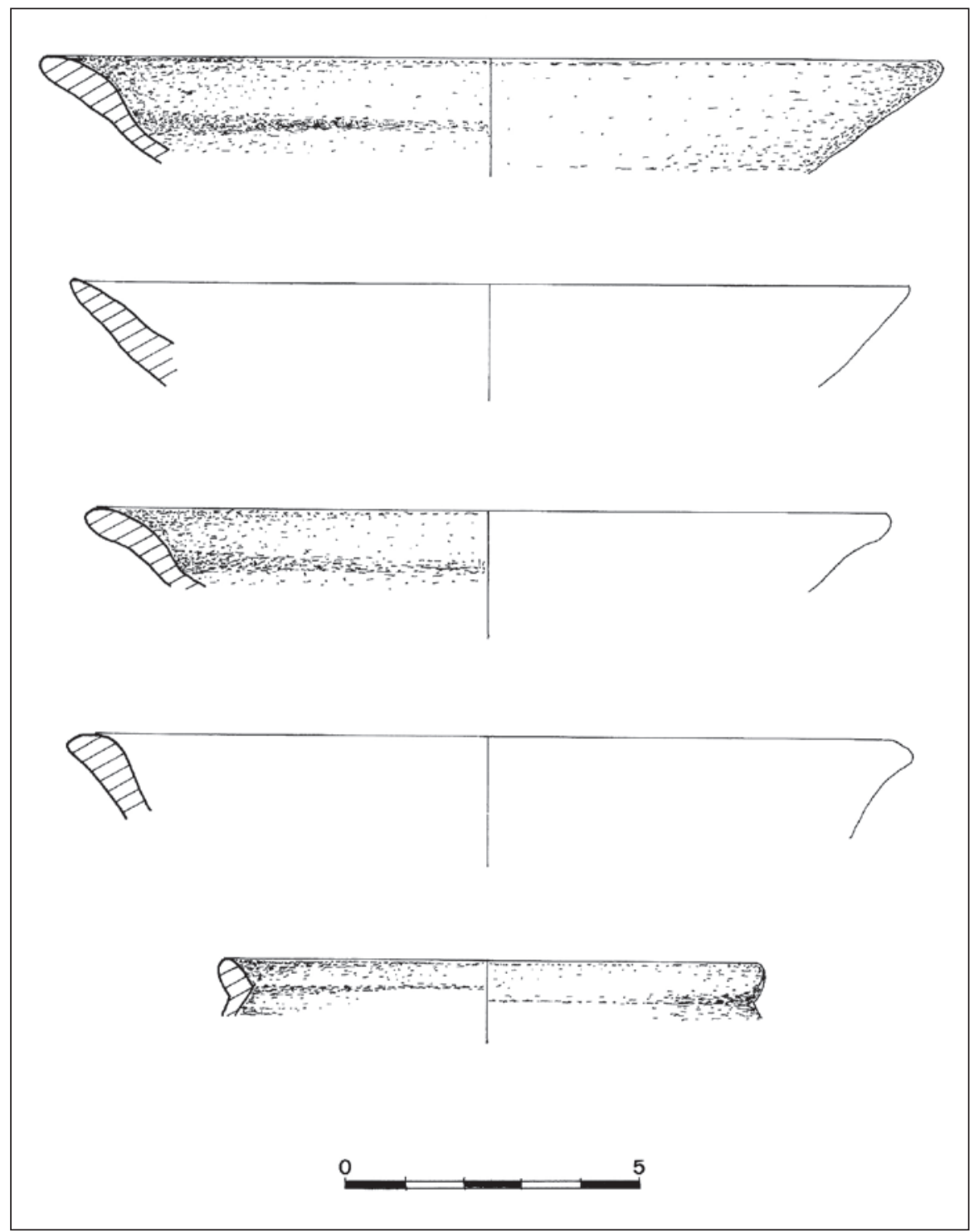

Fase II de Ruiz Mata (1993:278), es decir, durante el siglo VII a.C.

A recipientes de mayor formato corresponden los fragmentos con cuerpos de paredes altas, un poco exvasadas y base plana (Fig. 11). Algunos de ellos tienen dos asas a ambos lados, formadas por un semicírculo protuberante de tipo herradura. Son muy abundantes en el conjunto cerámico, con superficies normalmente sin tratar o alisadas, observándose en alguno de ellos reparaciones con lañas.

Son frecuentes entre las cerámicas a mano del Bronce Final-Hierro I, los soportes o carretes para recipientes (Fig. 12). Éstos están también presentes entre el material recuperado. A este tipo de recipiente pertenece un borde, apuntado y fino en el filo, bruñido por ambas caras y un baquetón que pertenece a la zona central. Se localizan también unos fragmentos pertenecientes a recipientes de forma esférica con paredes perforadas en su totalidad que muestran huellas de haber estado expuestas al calor. Este tipo de recipientes se interpretan siempre como queseras o coladores, aunque en algunos casos se les supone un uso metalúrgico en el proceso de copelación de plata. Éstos aparecieron cerca de un fogón, por lo que suponemos su utilización en alguna actividad realizada en el mismo.

También se recuperaron algunos objetos relacionados con telares o actividades domésticas. Se trata de varias fusayolas y pesas. 

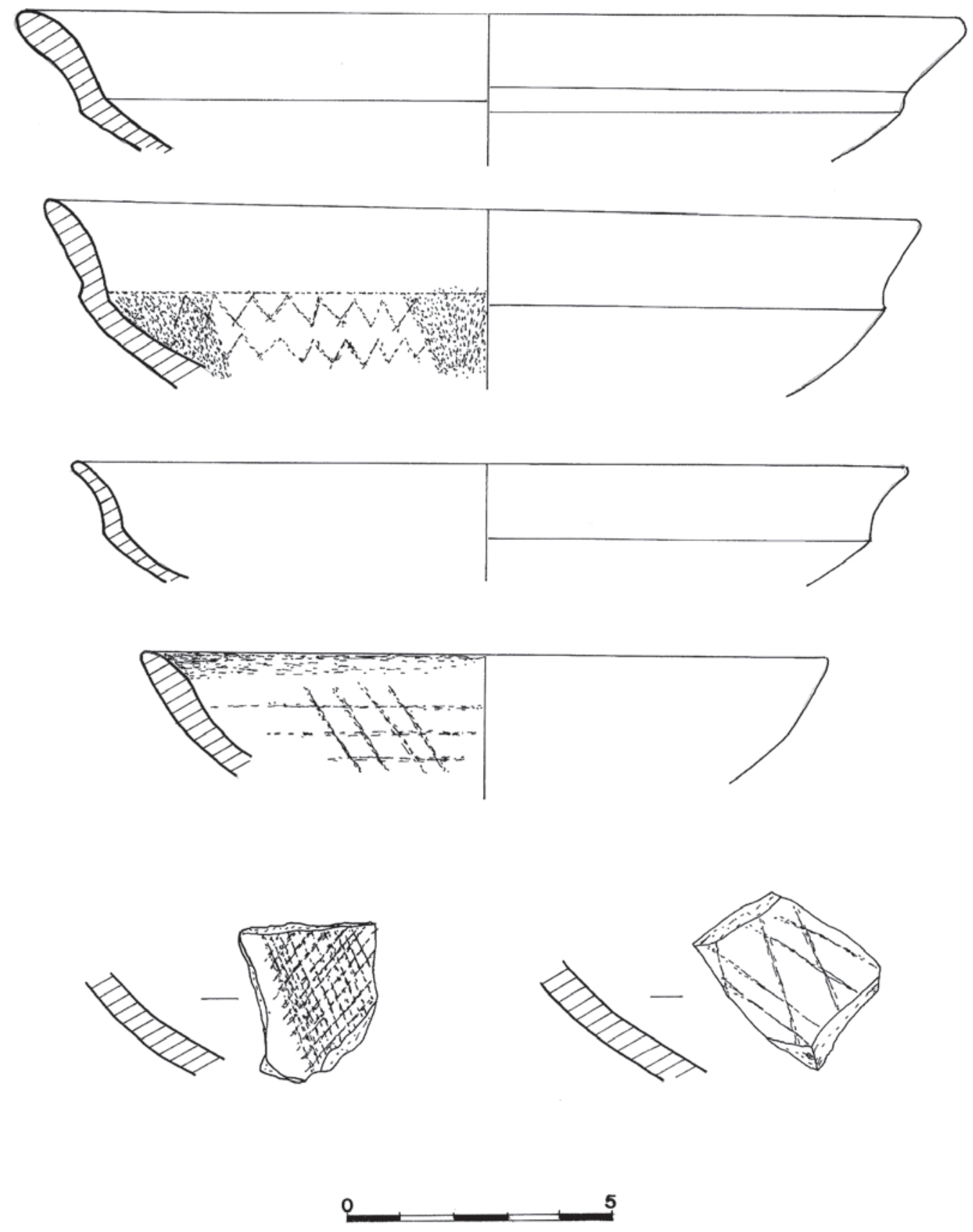

Figura 8. Material arqueológico realizado a mano del Bronce Final-Hierro I: Cuencos carenados o cazuelas 


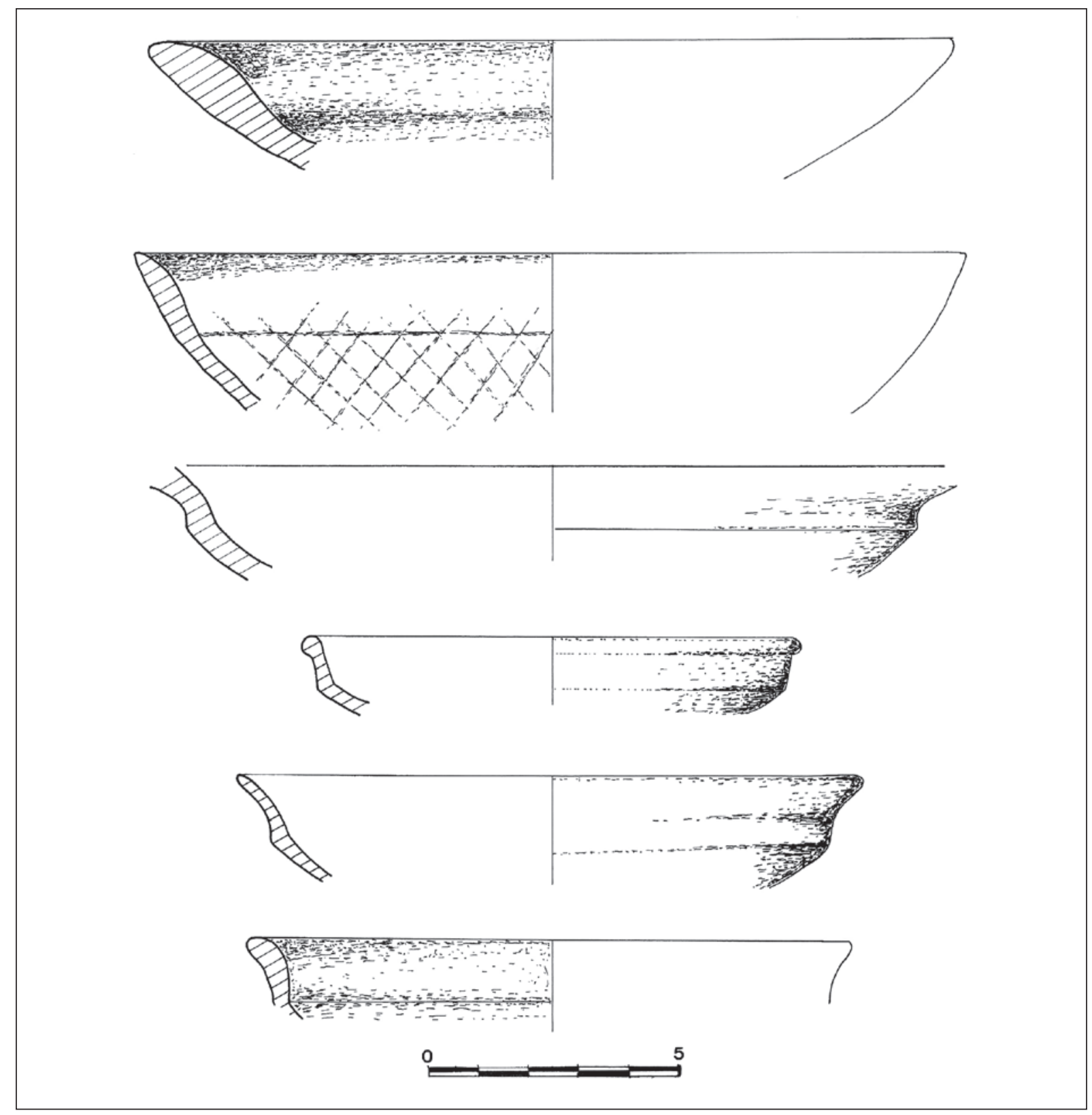

Figura 9. Material arqueológico realizado a mano del Bronce Final-Hierro I: Cuencos carenados o cazuelas

\subsection{Cerámica a torno fenicia}

a.- La cerámica fenicia de engobe rojo

\section{Lucernas}

Los recipientes con función relacionada con la iluminación, utilizando como combustible aceite o grasa animal con una mecha vegetal, son comunes durante el
Bronce Antiguo en Oriente, en el III milenio a.C. Hacia 1800 a.C., evolucionan a la forma cananea que conocemos de pequeño plato o cuenco de base convexa o plana con una o más piqueras o mecheros, formados por presión en el borde con los dedos cuando el barro aún esta tierno. En Fenicia y en toda su zona de influencia, incluyendo Chipre, predominan casi exclusivamente las lucernas de un solo mechero y de menor tamaño mientras que las occidentales, bicornes o con 


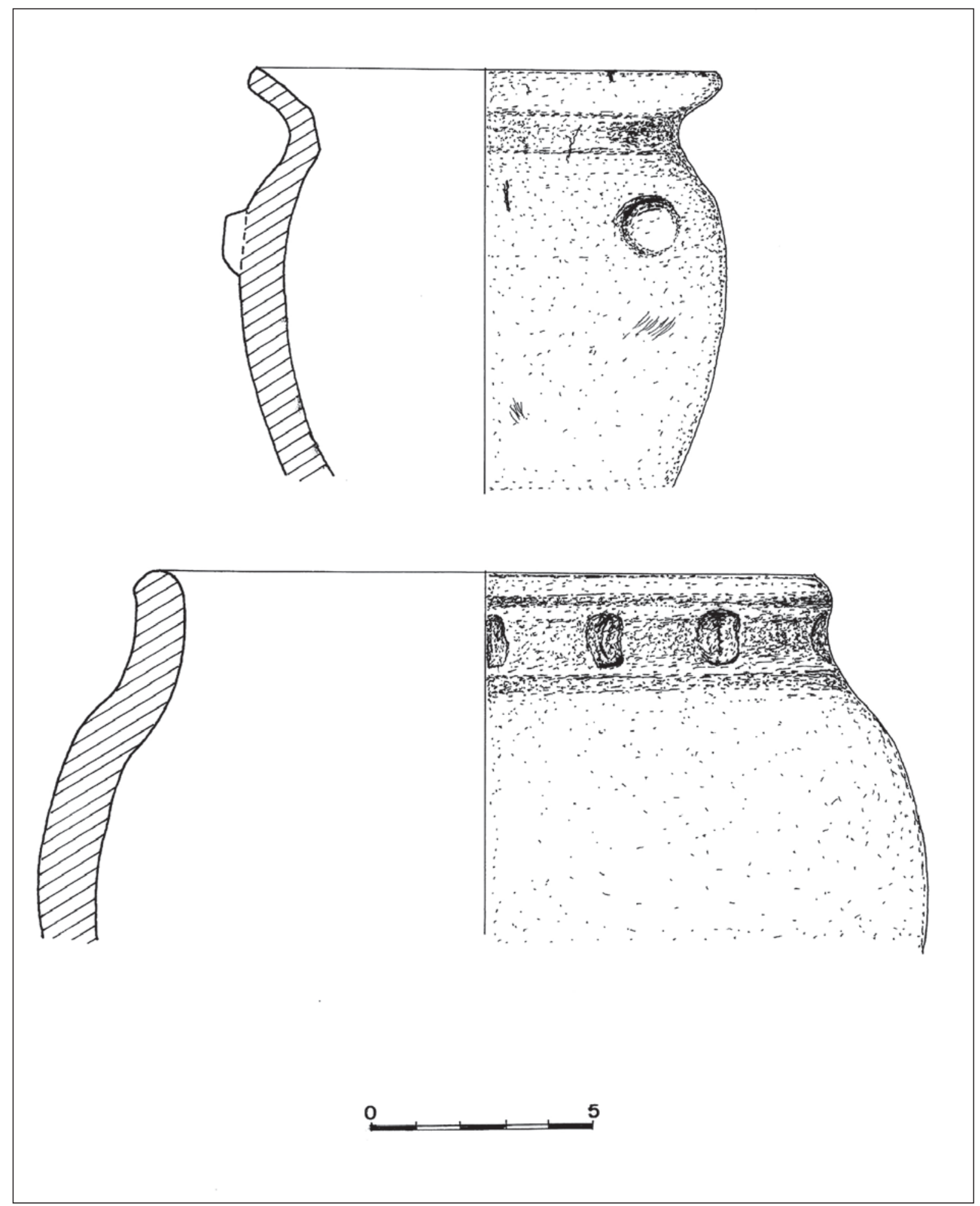

Figura 10. Cerámica a mano del Bronce Final: Ollas con decoración digitada 


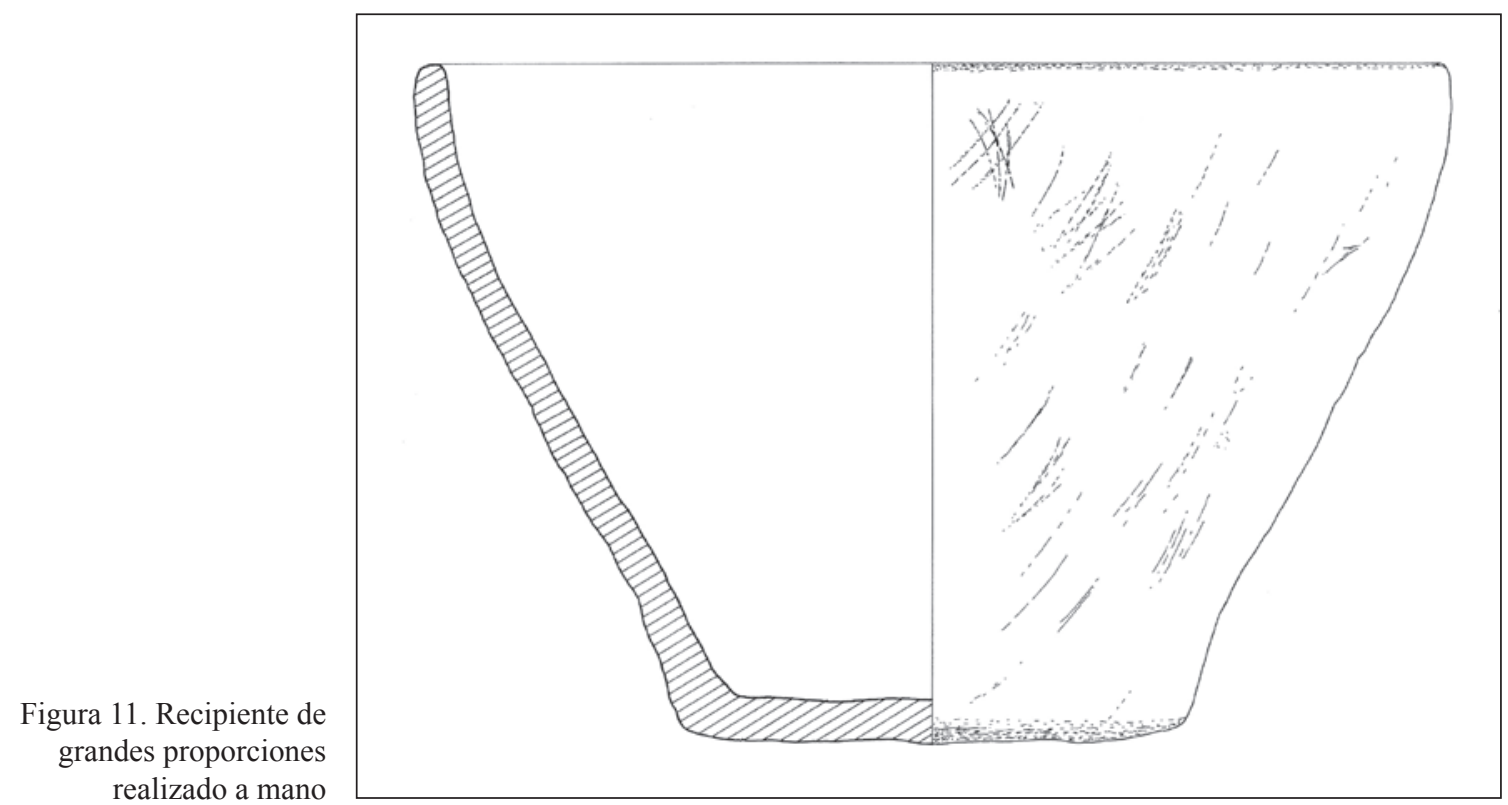

dos mecheros y engobadas, son más abundantes. En Occidente la lucerna fenicia evoluciona disminuyendo de tamaño y modificando la forma de sus mecheros, pequeños en los siglos VIII-VII a.C., se hacen más profundos en los siglos VI-V a.C. hasta llegar a cerrarse en los siglos IV-III a.C., cuando los productos griegos comienzan a ser cada vez más abundantes, de forma que son numerosas las de barniz negro halladas junto a las típicas del mundo fenicio-púnico, hasta la imposición final de las romanas.

Este grupo aparece representado en un total de trece fragmentos. Los restos más completos nos permiten decir que se tratan de lucernas de una sola mecha (Lám. VIII). El diámetro de estos recipientes oscila entre los 13 y $14 \mathrm{~cm}$ aproximadamente. Las pastas son muy depuradas y los engobes presentan una calidad y un bruñido excelentes. Todas las piqueras presentan huellas de uso, quemadas y manchadas de negro.

Platos

El plato de engobe rojo, predominante durante los siglos VIII-VI a.C. y utilizado en la mesa para contener alimentos, es un componente constante en la vajilla fenicia y su presencia en mayor o menor medida nos indica en cierta forma el nivel ocupacional de un yacimiento (Lám. IX). Sus engobes no nos sirven a la hora de precisar una cronología en función de la calidad del tratamiento, puesto que se ha detectado la coetaneidad de engobes rojos y marrones de aspecto esmaltado junto a otros mas aguados, predominando una ligera calidad en los más arcaicos, aunque en el Cerro del Castillo (Chiclana) son de gran calidad y se datan a finales del VII o principios del VI a.C.

Su tipología ofrece una gran diversidad en cuanto a variantes se refiere, los hay más o menos anchos y profundos, de bordes exvasados, rectos, curvos o engrosados, en ocasiones presentan acanaladuras o una arista al interior que marca su inicio, los fondos pueden ser

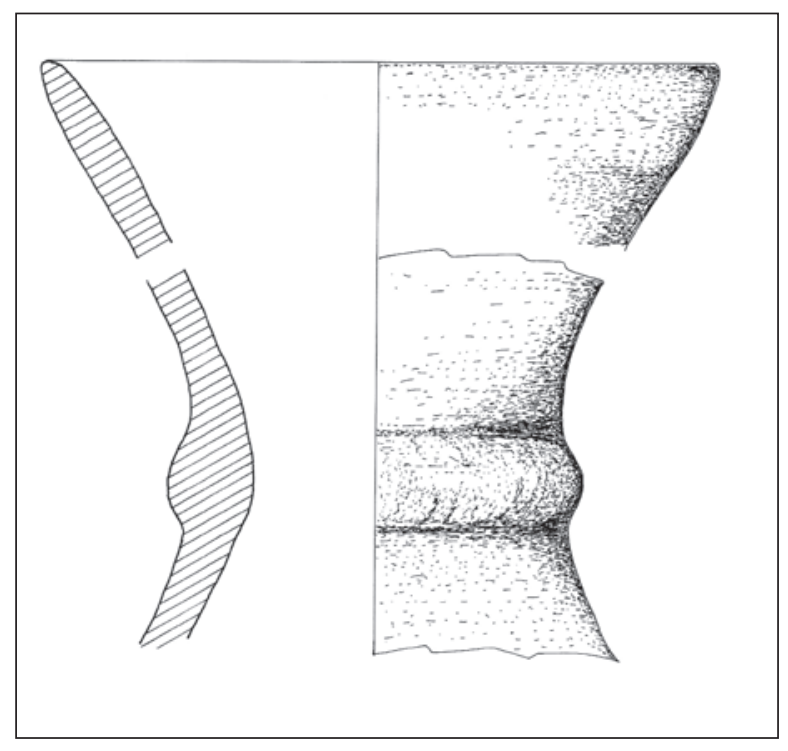

Figura 12. Fragmentos de soporte realizado a mano, con la superficie exterior bruñida 


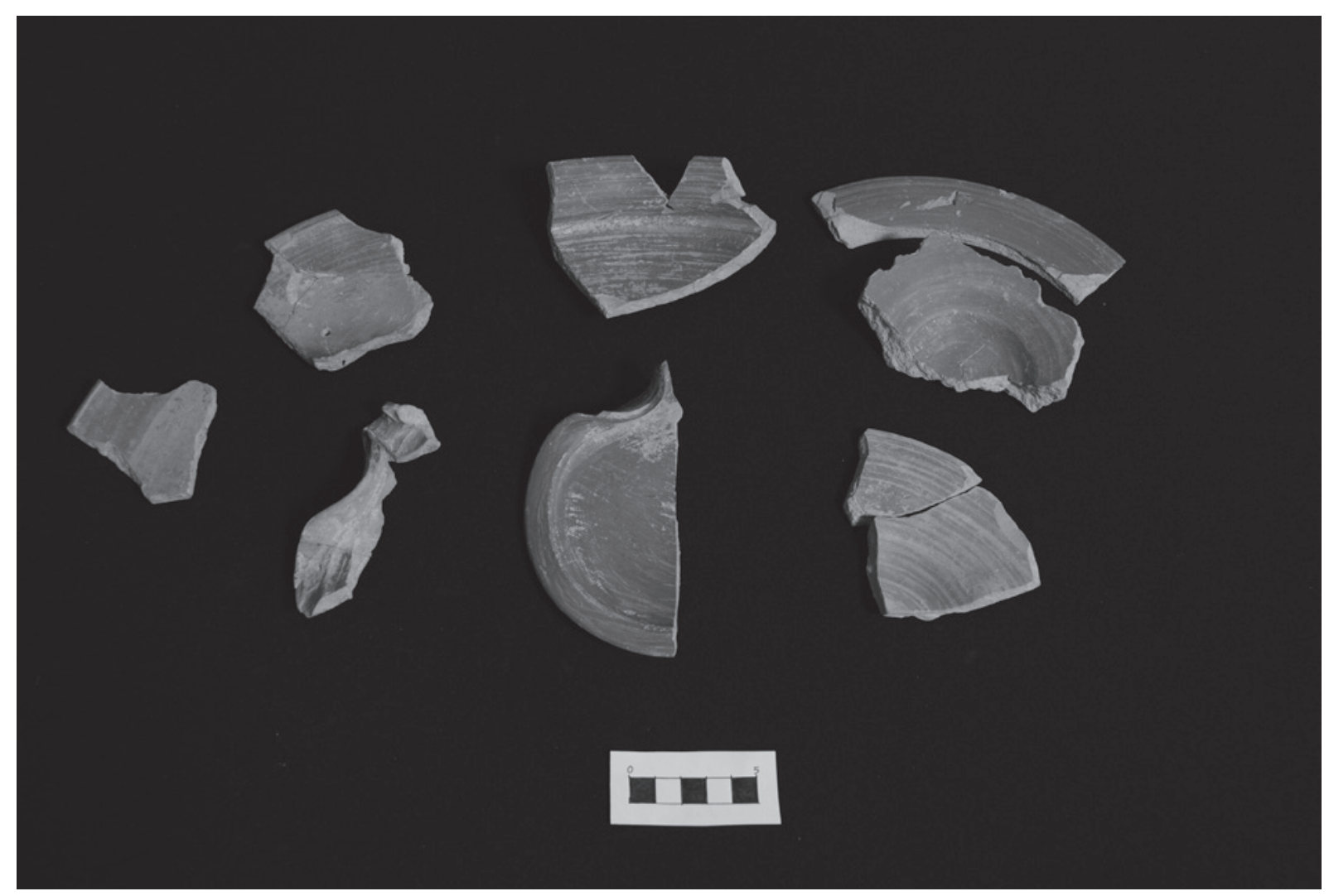

Lámina VIII. Lucerna de engobe rojo de una sola mecha

planos o curvos, con o sin pie. Tienden en el exterior a la forma troncocónica muy abierta, cóncava, con el borde ligeramente vuelto y la base cóncava. En el interior el borde se marca con una carena más o menos acusada que lo separa del fondo del plato. En las formas primitivas del siglo VIII a.C. halladas en la península, el perfil exterior, convexo con borde vuelto, es muy similar al de los platos orientales de Tiro V-IV, fechado por P.M. Bikai entre el 750 y 730 a.C. Se confirma en otras estratigrafías que hacia finales del siglo VII y principios del VI a.C. el labio horizontal del plato termina en una ranura. Establecer una cronología en función de la anchura del borde y del cociente del diámetro como plantea H. Schubart (1976: 179-196) nos parece algo complicado y de difícil comprensión debido a una serie de fenómenos a tener en cuenta tales como talleres, alfareros, estilos y diseños.

Representan el conjunto más numeroso encontrado en lo que a cerámica de engobe rojo de refiere (Fig. 13). La mayoría se localizan en el interior de las estructuras fenicias: estancias, viviendas y muralla presentando unos diámetros comprendidos entre los 20 y $27 \mathrm{~cm}$ aproximadamente. Algunos ejemplares desarrollan cierta curvatura hacia el exterior con una medida entre 5 y 6 $\mathrm{mm}$, presentando una incisión o ranura en el labio. Otros tienen el borde muy fino y vuelto hacia abajo, y enano de ellos se documenta un grafito en la parte exterior. En el fondo interior, donde se forma el pocillo, se observan diferentes medidas que oscilan entre los 4 y $10 \mathrm{~cm}$.

Las pastas cerámicas utilizadas son depuradas, presentando tonalidades ocres y naranjas; en ocasiones se observan desgrasantes como mica y sílice.

Se localizan también los platos "tipo Jardín", sobre todo en el estrato depositado en el exterior de la muralla que hemos interpretado como basurero. Este tipo de plato aparece en el Corte CA 80/A de Carmona, en los niveles 16-17 B y en el Estrato VII de Carmona (Pellicer y Amores 1985: 86, Fig.24, fragmento 12), en Puerto 6 en el Nivel IV (570-560 a.C.) (Fernández Jurado 1988-89: lám. XXXVI: 8, 9 y 10) y en Puerto 9 (570/560-590 a.C.) (Fernández Jurado 1988-89: 81). Miden $23 \mathrm{~cm}$ de diámetro aproximadamente y presentan acanaladuras por la pared exterior que corresponden a las marcas de dedos al realizarlos. 


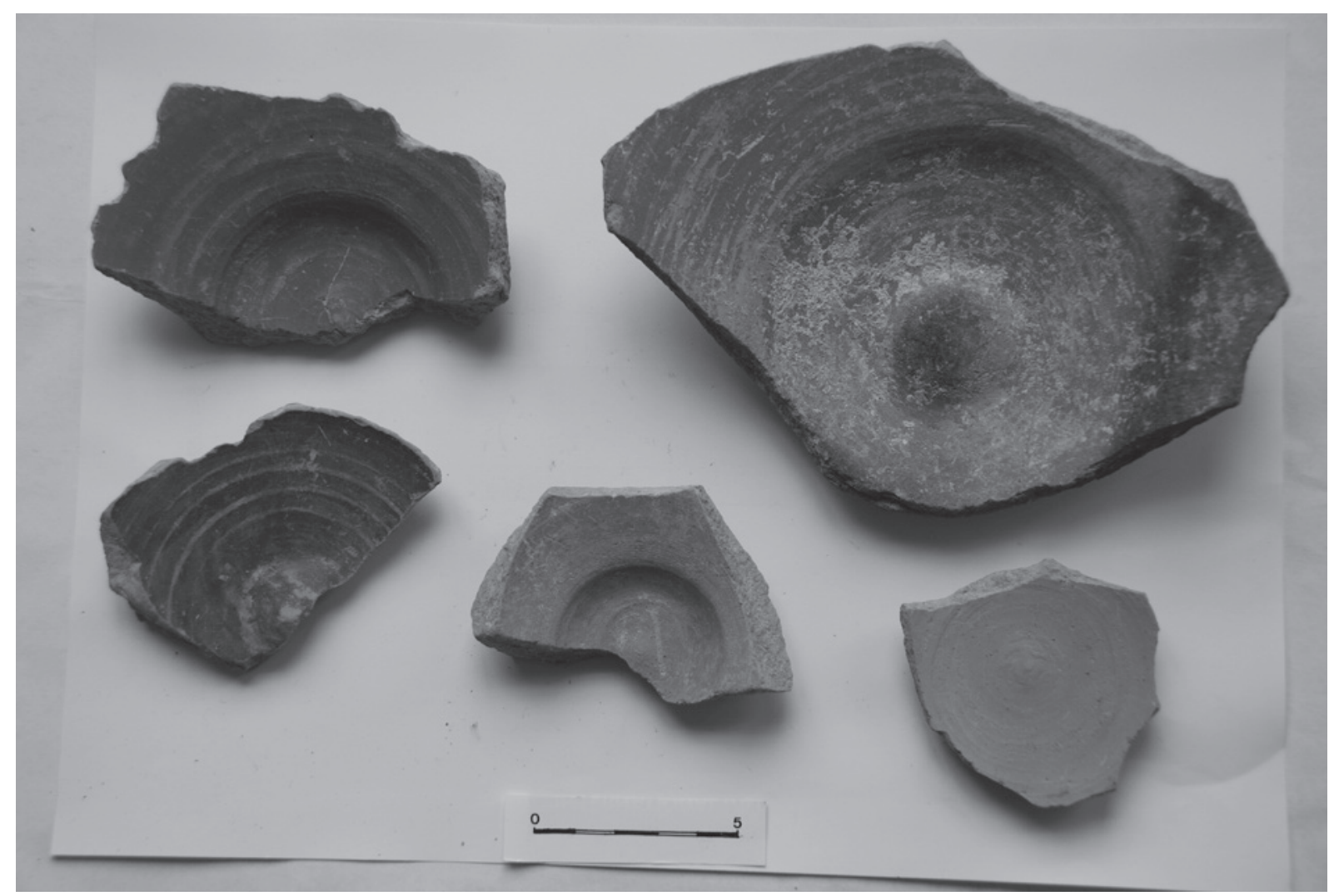

Lámina IX. Plato fenicio de engobe rojo

\section{Cuencos}

Es la forma que, junto a los platos, ofrece una gran variedad, tanto si son de engobe rojo como grises, pintados o sin tratamiento. Presentan formas semiesféricas o cuerpos carenados, con bordes rectos, engrosados, entrantes, inclinados, exvasados al exterior o acanalados. Los fondos son planos o curvos y en ocasiones rehundidos, pudiendo llevar un pie (Fig. 14: 2-4).

Los de engobe rojo, muy difundidos en el siglo VIII a.C., desaparecen en el siglo VI a.C., cediendo su lugar a piezas sin decorar que alcanzarán gran difusión en el mundo ibérico, sin olvidar los cuencos grises, que perduraran al igual que los pintados al menos hasta el siglo $\mathrm{V}$ a.C.

Aunque en un menor porcentaje, pero siendo también muy numerosos, aparecen los cuencos. Suelen ser de tamaños aproximados, con diámetros de $22 \mathrm{~cm}$; la única salvedad es que algunos presentan el borde simple, es decir, con el mismo grosor en toda la pared del recipiente y otros en cambio, tienen el borde engrosado al interior. Éste tipo recipiente es muy frecuente en todos los yacimientos fenicios de Andalucía Occidental y Oriental, formando parte también de las vajillas fenicias que aparecen en los asentamientos autóctonos del Bronce Final-Hierro de la campiña gaditana (Bueno Serrano 1988: 103). Las pastas son similares a la de los platos, e igual ocurre con los engobes, elaborados con una calidad excelente. La única diferencia que se aprecia en el conjunto es que algunos presentan toda la superficie interior cubierta hasta el borde, mientras que otros, sólo cubren la mitad superior de este. Otros ejemplares presentan engobe desde el borde hasta la mitad del recipiente, y sobre estos dos filetes negros, tratándose de una versión occidental y local de la decoración "black on red" oriental, junto al repertorio cerámico que estamos citando. En otros casos se decora el borde y se interrumpe hasta la mitad del vaso donde se vuelve a trazar otra línea de color rojo.

\section{Cuencos carenados o páteras}

Se trata de formas abiertas con carenas bajas y pequeños bordes exvasados. Los tamaños de boca son variables, entre 16 y $18 \mathrm{~cm}$. Las pastas son tan depuradas 


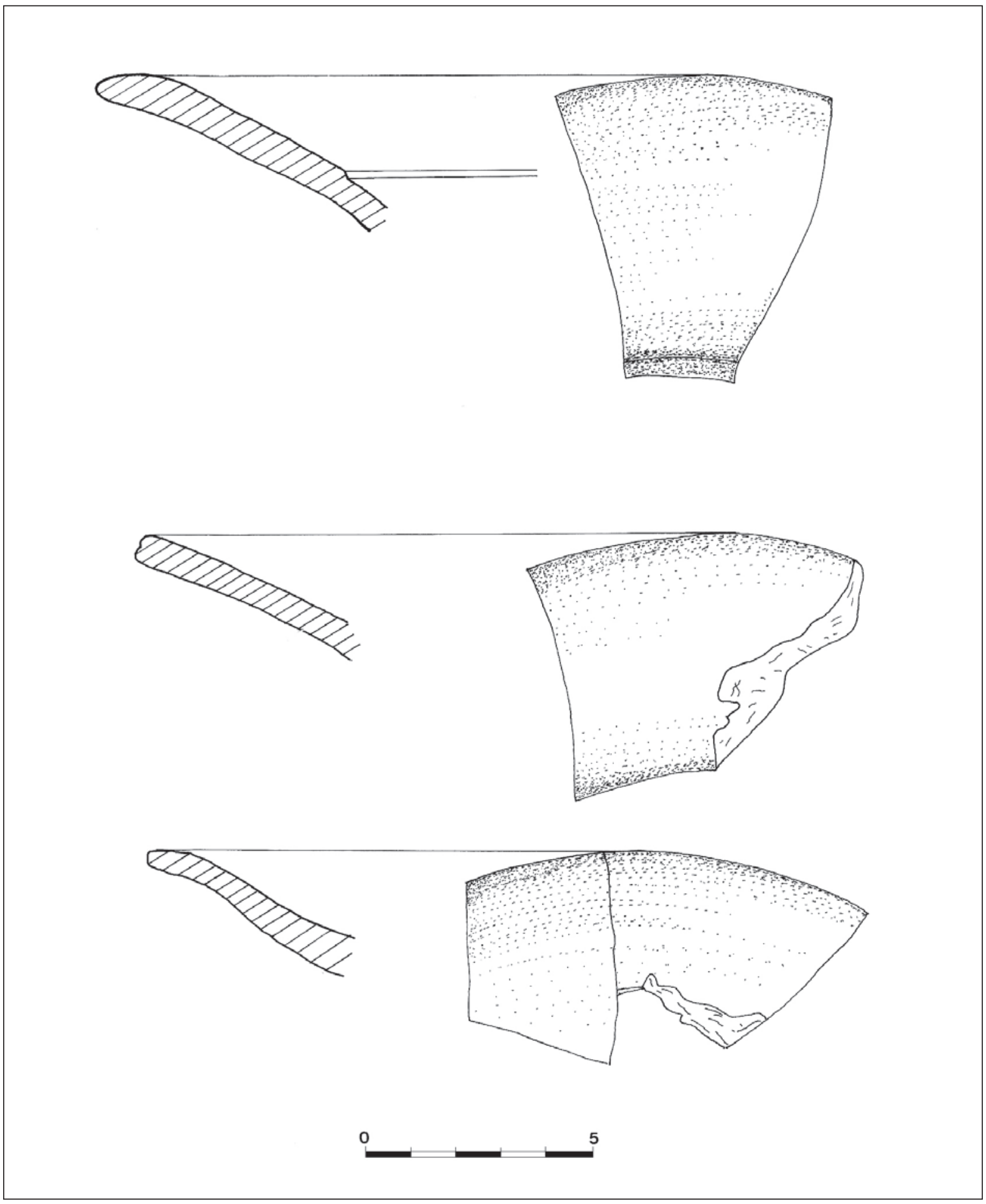

Figura 13. Platos fenicios de engobe rojo 


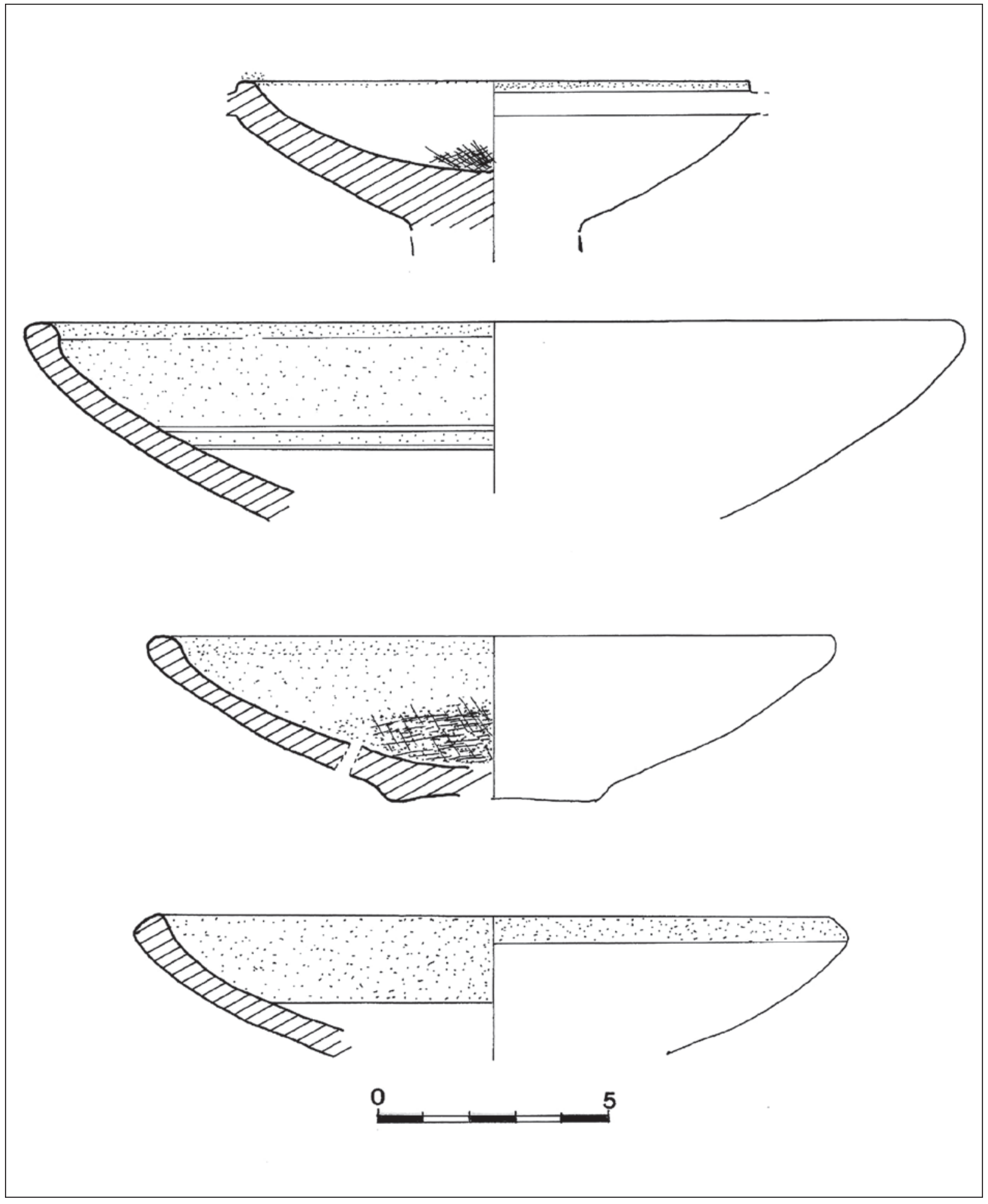

Figura 14. Dibujo de cuencos de engobe rojo 


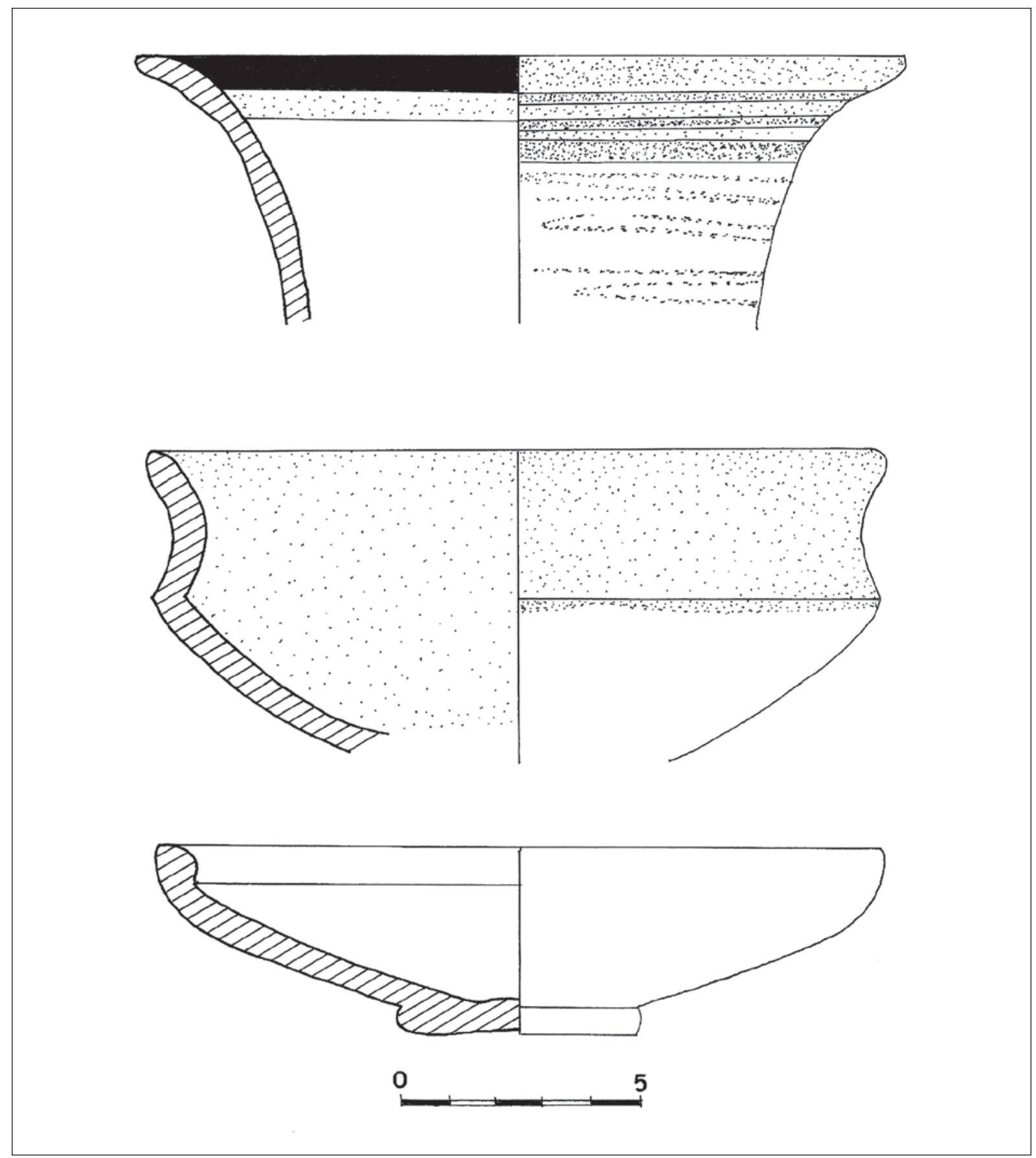

Figura 15. Dibujo de urna, cuenco carenado y cuenco

como las anteriores y los engobes oscilan entre el color marrón y el rojo (Fig. 15: 2). Se trata de un tipo que está documentado en el Castillo de Doña Blanca desde el siglo VIII a.C. (Ruiz Mata1992: 38, fig. 2), perviviendo durante el siglo VII a.C. (Ruiz Mata 1992: 84, fig. 20). En Morro de Mezquitilla se documenta desde los comienzos de la fundación fenicia (Schubart 1985: 153, fig. 5: b y d); en Huelva, en cambio, sólo aparecen a partir del siglo VII a.C. (Rufete 1988-89: 31-34, fig. 7 y 8$)$. 
Jarritas y ampollas

Las jarras con engobe rojo se utilizaron como contenedores de líquido, agua, vino o aceite, y se documentan en Oriente desde fines del II milenio a.C., evolucionando su forma desde el siglo IX a.C., con los tipos arcaicos de cuerpo globular, hombros o cuello troncocónico cóncavo, boca trilobulada y asa geminada o simple, fechados en los siglos IX-VIII a.C., hasta los tardíos, con el cuello cónico rectilíneo convexo, del siglo VII a.C. típicos de Occidente, que aparecen en los niveles IX, segunda mitad del siglo IX a.C., y IV (760 740 a.C.) de Tiro.

Es una forma frecuente en los yacimientos fenicios de la Península Ibérica, habiéndose hallado ejemplares completos en diferentes necrópolis (Laurita, Trayamar, Toscanos y Cerro del Mar), por lo que se les aducía un carácter funerario. En los establecimientos fenicios de Mezquitilla, Cerro del Villar, Adra, La Fonteta, Chorreras y Doña Blanca solo han aparecido fragmentos, al igual que en yacimientos tartesios como Carmona y el Carambolo.

Las jarras y ampollas, aunque en número reducido, se encuentran presentes en unos nueve fragmentos que corresponden a asas y golletes. Las pastas presentan características similares a las anteriores y los engobes la misma calidad.

Jarros de boca de seta

Los jarros de boca de seta tienen un amplio labio fungiforme, cuello alto y estrecho, cuerpo globular $\mathrm{u}$ ovoide, base algo cóncava y una pequeña asa semicircular de sección circular, situada en la parte inferior del cuello y hombros. Se conocen ejemplares donde el engobe rojo ocupa todo el vaso; otros cuya decoración, a bandas rojas y negras, solo abarcan la parte superior; y algunos, los más tardíos, sin ningún tipo de coloración. Debido a la forma de la boca debió usarse para contener sustancias perfumadas o bálsamos para ungüentos que se extendían sobre su superficie plana.

Su origen aún no está claro, habiendo aparecido sus prototipos en el Bronce Reciente de Siria, Palestina y Chipre, en la segunda mitad del II milenio a.C., como una evolución de ciertos vasos micénicos o como derivación de los de tocador egipcios. Teniendo en Oriente sus formas más arcaicas, del siglo XIV-XIII a.C. en Ugarit, del siglo X-IX a.C. se hallaron en Tell-BeitMirsim, Ain Shems y Jericó, del siglo IX a.C. en Meggido y Lakish, del siglo IX-VIII a.C. en Khaldé, Achiv y Tiro y del siglo VII-V a.C. en Athlit.
$\mathrm{Su}$ cronología en Occidente abarca desde el siglo VIII hasta principios del siglo VI a.C., localizándose los ejemplares más antiguos en Morro de Mezquitilla (Schubart 1985: 141-174), Doña Blanca (Ruiz Mata 1985: 246, fig.2), Cerro de San Cristóbal y El Carambolo, todos ellos datados entre mediados y la segunda mitad del siglo VIII a.C. Del siglo VII a.C. son los de Trayamar (Negueruela 1983: 262) y Cerro del Mar, en tanto que de principios del VI a.C., sería el procedente de Cortijo de Montañés.

Entre los fragmentos cubiertos de engobe rojo se ha identificado uno como parte del cuello de un oinocóe. La pasta es anaranjada y presenta desgrasantes de mica. Las paredes del recipiente son finas y bien cuidadas.

\section{Quemaperfumes}

Otros recipientes que se documentan son los conocidos habitualmente como quemadores de perfumes. $\mathrm{Su}$ uso parece tener un sentido ritual, bien para quemar perfumes y sustancias aromáticas, bien como lamparillas. Están formados por uno o dos platos o cuencos que pueden presentar una carena en uno o en ambos recipientes, aunque se conocen con las paredes de tendencia rectas. El que consta de dos cuerpos superpuestos se halla unido mediante un vástago hueco que parte del centro del inferior. Los de un solo recipiente están formados por un cuerpo cóncavo que reposa sobre un vástago circular que lo eleva en forma de copa.

Los prototipos se crean en Oriente donde los encontramos en yacimientos como Kitión en Chipre, de donde procede un ejemplar fechado a principios del siglo VIII a.C. En el Cerro del Castillo hay dos fragmentos que pertenecen al mismo recipiente (Fig. 14: 1). Tiene forma de casquete esférico, aunque le faltaría un filo que parece arrancar a la mitad del borde, y un diámetro de $11,5 \mathrm{~cm}$. Conserva el arranque del pie que lo elevaba en forma de copa, presentando huellas de uso y resto de decoración en rojo.

\section{b.- Cerámica común}

\section{Trípodes}

Otro tipo cerámico habitual en los asentamientos fenicios, sin que se hayan localizado, al menos hasta el momento, en necrópolis y poblados indígenas es el trípode. Presenta un fondo curvo, tres pies cortos de sección cuadrangular o con tendencia triangular que se separa del cuerpo mediante una acanaludara. Aparecen tanto sin tratamiento como con engobe rojo sobre el borde. 
Su funcionalidad y evolución presenta dudas aunque se ha sugerido que pudieron usarse para moler, guardando relación con los morteros y teniendo su origen en los trípodes orientales hechos en piedra. $\mathrm{Su}$ cronología comprende desde el siglo VIII a.C. (Casa de Montilla, Chorreras y Doña Blanca) hasta el siglo V a.C. (Cádiz).

Se localizan siete fragmentos de trípodes similares a los que aparecen en el Castillo de Doña Blanca (Ruiz Mata y Pérez 1995: 82, fig. 18), entre las cerámicas fenicias occidentales del siglo VIII a.C., con acanaladura bajo el borde y otros similares a formas del siglo VII a.C. (Ruiz Mata y Pérez 1995: 85, fig. 21).

\section{Lebrillos}

Son recipientes de gran diámetro, con bordes rectos o engrosados hacia el exterior, paredes esféricas separadas del borde mediante una carena muy marcada y fondos curvos. Aparecen en el siglo VI a.C., encontrándose muy difundidos entre los asentamientos ibéricos y turdetanos, aunque se localizan también en yacimientos de tradición semita y dentro de zonas de hábitat en el ámbito fenicio-púnico. En el Castillo de Doña Blanca están presentes entre las cerámicas del siglo VI a.C. (Ruiz Mata y Pérez 1995: 87, fig. 23). Continúan a lo largo de los siglos V-IV a.C., aunque con las carenas menos marcadas.

En Chiclana se registraron un total de diez fragmentos de lebrillos, cuyas pastas son de color ocre o verdes.

\section{Morteros}

Parecen ser los continuadores de los cuencos-trípodes que hemos visto con anterioridad según algunos autores. Surgen a partir del siglo VI a.C., tienen bordes muy gruesos y anchos de sección triangular, en ocasiones con acanaladuras, cuerpos redondeados y bases planas, siendo abundantes sobre todo durante los siglos V-IV a.C., cuando los bordes, más gruesos y menos triangulares, pueden llevar una hendidura en su parte superior. Sólo se conocen ejemplares procedentes de poblados en el mundo fenicio-púnico, siendo corriente su presencia en yacimientos indígenas.

Varios de estos morteros se han documentado en Chiclana, similares a los que aparecen en el Castillo de Doña Blanca en los siglos IV-III a.C. (Ruiz Mata y Pérez 1995: 91, fig. 27).

\section{Anforas}

Son recipientes de almacenamiento y transporte que presentan una amplia gama y diversidad ya que pueden llevar decoración pintada, engobe rojo o bien ningún tratamiento. Como es lógico, en un yacimiento de indudable importancia comercial las ánforas son abundantes, y aunque requieren un estudio más profundo, se han distinguido varios tipos. La más frecuente es la de "saco" de cuerpo piriforme o de tendencia globular con una carena alta y marcada, cerca de la cual nacen las asas de sección circular; sus bordes tienen sección triangular o son más rectos y exvasados al exterior, y fondos curvos. Las más recientes muestran un estrechamiento del cuerpo bajo la carena; sin embargo la mayor diferencia parece estribar en las formas de los bordes, generalmente más modernos los engrosados y más arcaicos los de tendencia recta. Correspondientes al tipo T-10.1.1.1 de Ramón Torres (1995), son cuatro bordes que se fechan en la mitad o segundo cuarto del siglo VIII a.C. (Fig. 16: 3, 4, 5). La pasta cerámica es de color ocre, con desgrasantes silíceos. Se trata de un modelo anfórico de gran importancia ya que es el primero que se fabricó en los centros fenicios del área del Estrecho de Gibraltar o, al menos, en muchos de ellos. A otro tipo, al T-10.1.2.1 (Ramón Torres1995), corresponden la mayor parte de las ánforas recuperadas, con una cronología que se fechan a partir del segundo cuarto o mitad del siglo VII a.C. (Fig. 17). La mayoría presentan una pasta cerámica de color ocreanaranjado, con desgrasantes silíceos. A este tipo corresponden los fragmentos que fueron recuperados en los niveles de relleno excavados en el exterior de la muralla, considerados como pertenecientes a una zona de vertido de basuras y materiales inservibles. Ánforas similares aparecen en el cercano yacimiento del Castillo de Doña Blanca, donde se datan desde finales del siglo VIII a.C., y están presentes en contextos indígenas desde al menos el siglo VII a.C., siendo el tipo de ánfora más difundido. En las postrimerías del siglo VII a.C., se detecta su fabricación en lugares indígenas bajo influencia fenicia.

A un momento más avanzado, cronológicamente hablando, pertenecen los fragmentos del tipo T-10.2.1.2 de Ramón Torres (1995), que se fechan en la segunda mitad del siglo VI a.C., concretamente en 530-510 a.C. El lugar de fabricación de estos tipos de ánforas se sitúa en los centros fenicios del área del Estrecho de Gibraltar. Seguramente también se fabricaron en los hornos de Kuass.

También está representado el tipo T-1.3.1.1 de Ramón Torres (1995), derivado de T-1.2.1.1. Se data este 


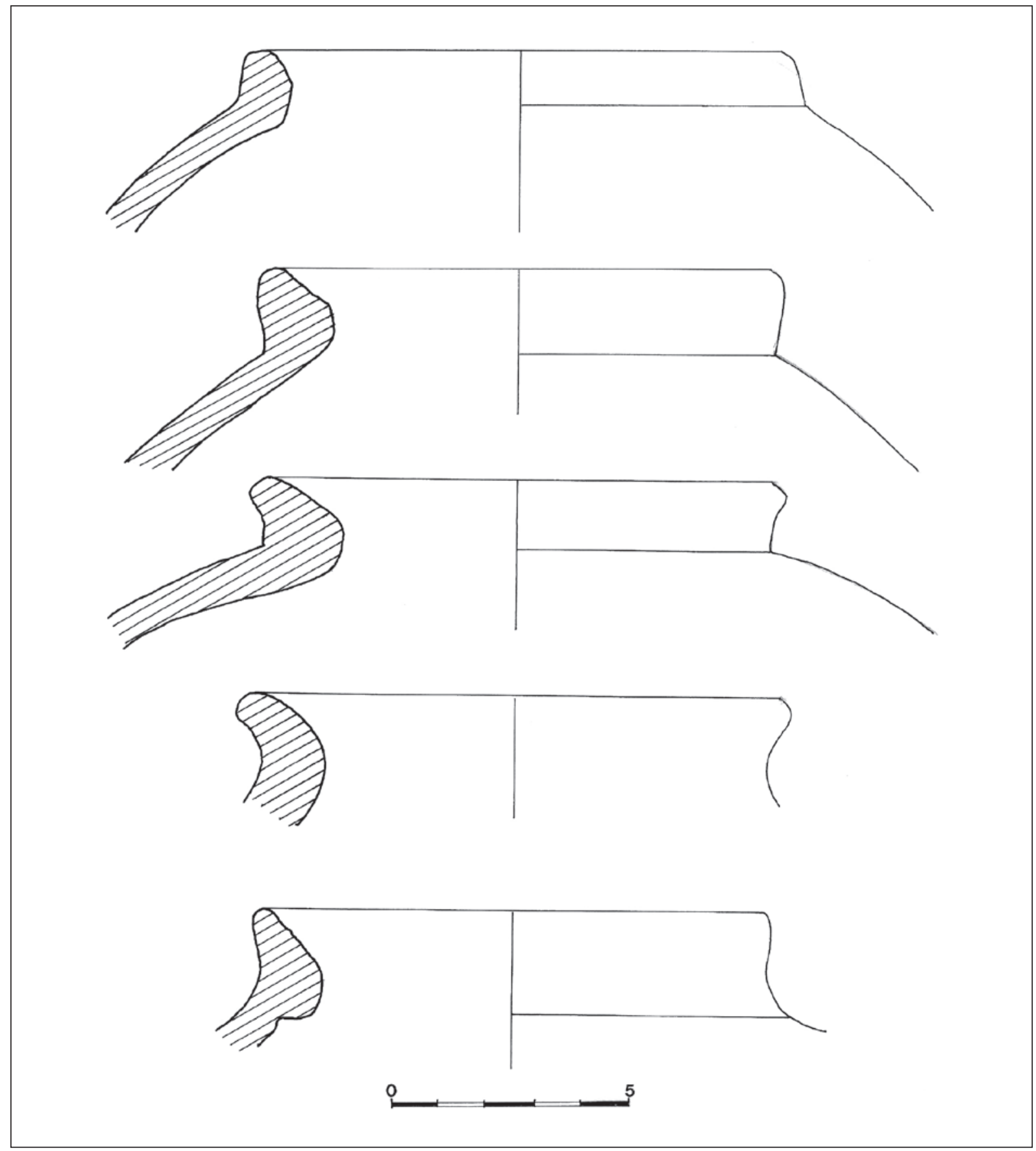

Figura 16. Ánforas

tipo de recipiente hacia el siglo $\mathrm{V}$ y finales del VI a.C. Entre el repertorio está también presente otro recipiente anfórico de cuello corto, que se corresponde con el tipo T-1.3.2.4 de Ramón Torres (1995); se fabricó en el área suroriental de la Península Ibérica, como Villaricos y otros centros próximos.
Así mismo se han clasificado dos bordes del tipo $\mathrm{T}-2.1 .1 .2$. Se trata de un tipo de relativa trascendencia en la trayectoria subsiguiente de una serie de formas púnicas del Mediterráneo Central. Se fechan a finales del siglo VII a.C. y primer tercio o cuarto del siglo VI a.C., siendo su momento álgido entre 600-575 a.C. 


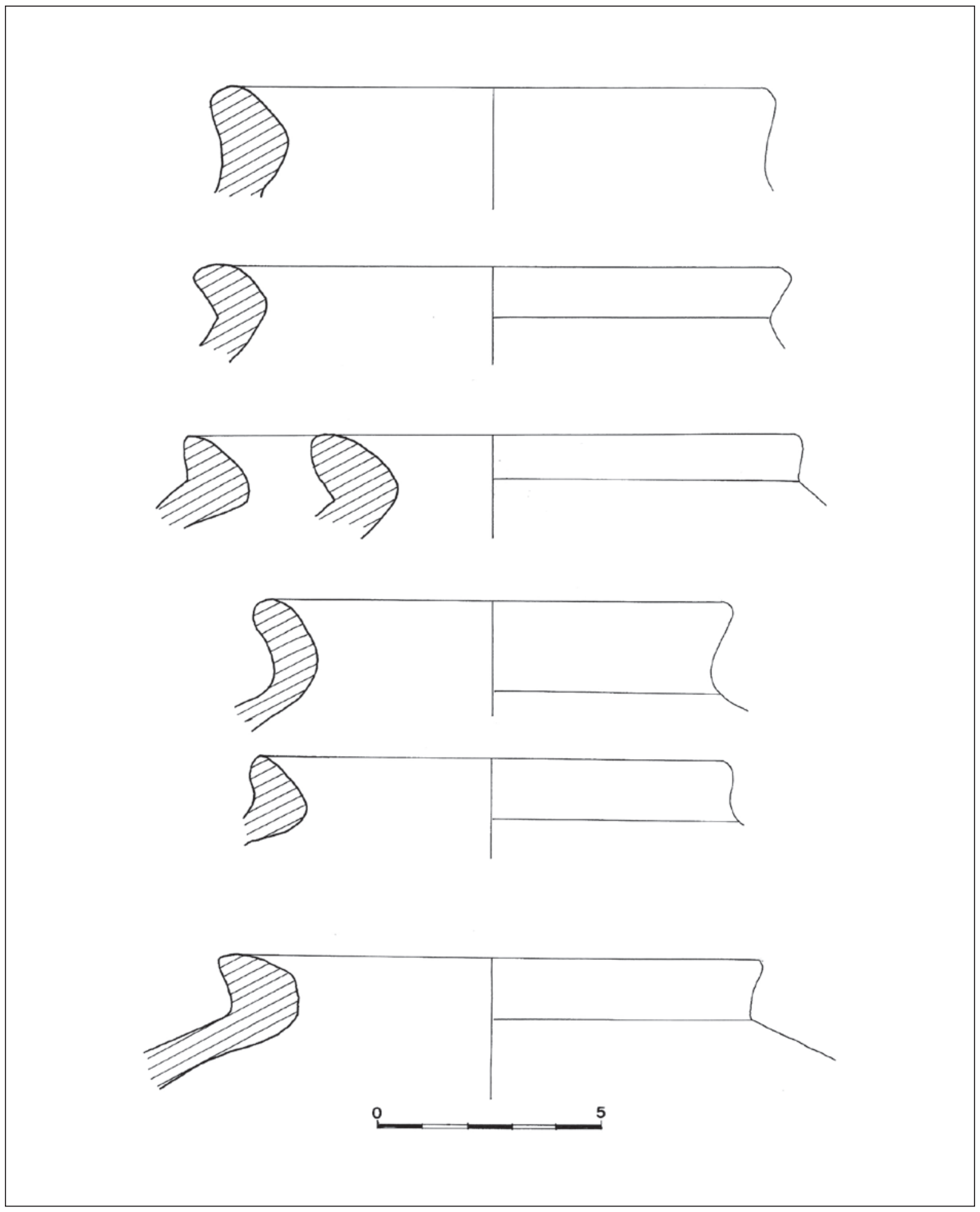

Figura 17. Ánforas 
Igualmente están presentes algunos bordes del tipo T-11.1.1.1, datados en los últimos decenios del siglo VI o primer tercio del siglo $\mathrm{V}$ a.C.

Pesas

Se ha registrado una pieza circular, plana, de pasta fina y cocción oxidante, con dos perforaciones que hemos pensado que se trataría de una pieza de telar, una pesa; mide $7 \mathrm{~cm}$ x $0,50 \mathrm{~cm}$.

\section{c. Cerámica pintada}

Píthoi

Estos vasos, utilizados como recipientes de almacenaje, son habituales en los poblados fenicios y su presencia es bastante normal en los asentamientos indígenas. Sus prototipos se sitúan en Palestina y en las ciudades fenicias desde el II milenio a.C.; presentan una base plana, cuerpo ovoide o esférico, separado del cuello por una leve carena. Dicho cuello tiene forma de cono y bordes engrosados al exterior que pueden ser tanto rectos como inclinados. Suelen llevar dos, tres y hasta cuatro asas dobles de sección circular o geminada que finalizan en el borde. La mayoría aparecen decorados con bandas polícromas que se superponen sobre un fondo de engobe crema. Algunos presentan motivos geométricos a la altura del cuello (serpentiformes y estrellas) (Lám. X; Fig. 18).

Los cuellos se hacen más cortos y los fondos comienzan a ser curvos a partir del siglo VI a.C., así como desaparece la carena que separa el cuello del borde, el cual presenta un saliente menor, para transformarse, en el siglo IV a.C., en un borde recto. En el sector excavado del yacimiento fenicio del Cerro del Castillo aparecen también varios cuerpos globulares muy fragmentados con la misma decoración que adolecen de bordes y cuellos; entre ellos, merece especial mención uno que contenía restos de alimentos, concretamente caracoles.

Esta forma se corresponde con el tipo II.2.B.b.2 en la clasificación de Belén y Pereira (1993). En Alboloduy, fue hallada una pieza completa que se fecha a fines del siglo VIII o principios del VII a.C.; también en el siglo VII a.C. están presentes en el Cerro de la Mora, Mezquitilla, Toscanos, Guadalhorce y Frigiliana; en el Bajo Guadalquivir se constatan en la Cruz del Negro, Alonso y Tejada, así como en Huelva (Belén y Pereira 1993: 323). También encontramos

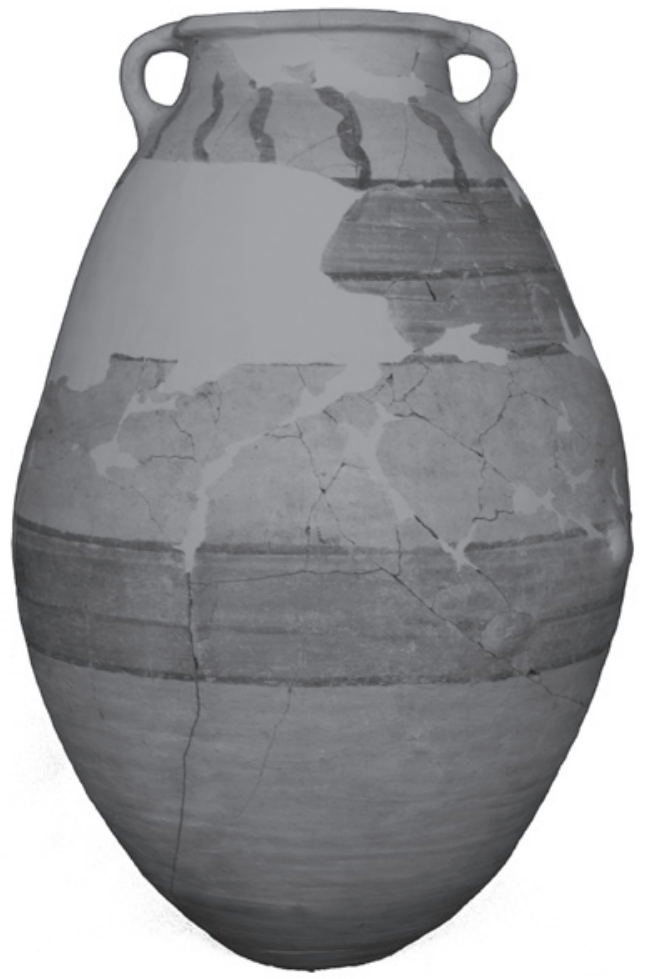

Lámina X. Píthos fenicio hallado en el interior de una caserna de la muralla

paralelos en el cercano yacimiento del Cerro del Castillo de Doña Blanca, en los siglos VII-VI a.C. (Ruiz Mata 1985: 262, fig. 8, frag.1; Ruiz Mata y Pérez 1995: 66)

El ejemplar que apareció casi completo junto a la muralla y próximo a la tahona mide $64,2 \mathrm{~cm}$. de altura, $18,5 \mathrm{~cm}$. de diámetro en el borde y $38 \mathrm{~cm}$. en la parte más ancha del cuerpo.

\section{Cuencos de borde simple}

Entre los recipientes cerámicos decorados con policromía y a bandas, están también presentes los cuencos hemiesféricos de borde simple. Similares aparecen en el Castillo de Doña Blanca y se fechan en el siglo VII a.C. (Ruiz Mata y Pérez 1995: 65 y 84). Aparecen junto a los platos de engobe rojo de borde ancho y a los cuencos carenados cubiertos de engobe rojo. 


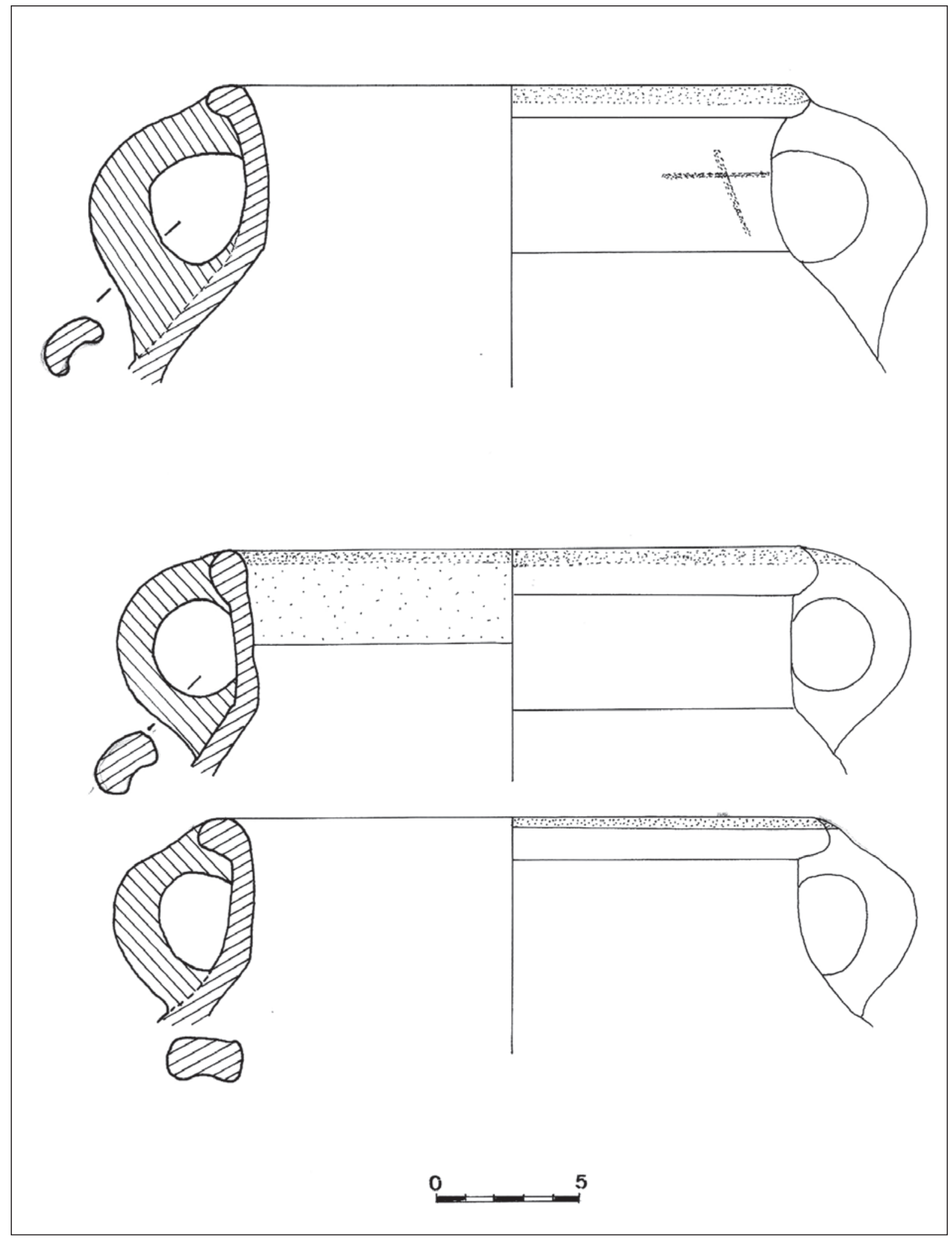

Figura 18. Pithos 
Cuencos carenados

Este tipo de recipiente está constituido por un cuerpo inferior elíptico poco profundo, y un borde vuelto al exterior, separado del resto del vaso por una carena. Se denominan también copas y presentan tamaños homogéneos. Los diámetros del borde oscilan entre 12 y $17 \mathrm{~cm}$ y presentan las superficies tratadas, alisadas y cubiertas de engobe y bandas de varias tonalidades, preferentemente negras, rojas y ocres. Aparecen en contextos del siglo VII a.C. en el Corte 5 del Cerro del Villar, y en otros yacimientos indígenas como el Carambolo Alto (Amores 1995) y campiñas litorales gaditanas (Bueno Serrano 1998). Asimismo, se hallan en contextos de finales del siglo VII y principios del siglo VI a.C. en el estrato $1 \mathrm{a}$ y $1 \mathrm{~b}$ de Cerro del Prado y también en contextos del siglo VI a.C. en el Castillo de Doña Blanca (Ruiz Mata 1992: 43). A éstas cerámicas se les atribuye cierta influencia griega por su decoración, en concreto cierta inspiración jonia, debido a que a partir de la primera mitad del siglo VI a.C., se produce la llegada de cerámica griegas a los yacimientos fenicios del Sur peninsular.

\section{Urnas}

También se denomina a este tipo de recipientes ánforas de cuello o urnas de "tipo Cruz del Negro" (Fig. 15: 1). Dentro de esta categoría se han incluido las grandes vasijas cerámicas según la forma del cuerpo inferior o primer cuerpo. Suelen estar decoradas con bandas policromas. Este tipo de vaso se localiza en gran cantidad de yacimientos, aunque en un principio se las vinculó principalmente con las necrópolis indígenas por su constatación en los cementerios tartésicos del Bajo Guadalquivir y Huelva. Sin embargo, el desarrollo de las investigaciones ha permitido constatar su existencia también en zonas de asentamiento, e incluso su posible fabricación en asentamientos autóctonos como en la campiña gaditana, estando presente en la mayoría de los asentamientos rurales, como Salado, Villarana, Vaina, Campín Bajo, Grañina, Casa de Rocío (Bueno Serrano 1998). En el Castillo de Doña Blanca aparecen tanto en el poblado como en la necrópolis, en el Túmulo 1 (Ruiz Mata y Pérez 1995).

A este tipo de cerámicas pintadas corresponde uno de los fragmentos hallados, con cuello alto y borde de paredes muy finas, vuelto al exterior. Presenta decoración de bandas policromas paralelas por el interior y por el exterior. Las bandas presentan varios colores marrones, negros y rojos. Vasos de características similares aparecen en la excavación de El Marqués de Saltillo (Carmona, Sevilla) (Belén y otros 1997: 90, 91 y 196) y se fechan entorno a 590-530 a.C. Otro borde, aunque fragmentado, es similar a otro hallado en las excavaciones de la Casa-Palacio del Marqués de Salti1lo, donde se registra en el Estrato 48, que se fecha a finales del siglo VI a.C. (Belén y otros 1997: 199-200). Igualmente documentamos fragmentos correspondientes a piezas de boca estrecha y cuello alto clasificables en la tipología al uso como urnas. La mayoría presentan las superficies muy cuidadas. Piezas similares encontramos en la zona de Málaga con cronología del siglo VII a.C. (Recio 1993: 127-141) y en el Cerro del Villar aparecen en gran cantidad en el Estrato 1a del corte 5, que se data en el siglo VI a.C. (Aubet 1999: fig. 72: 116); en El Castillo de Doña Blanca, en El Puerto de Santa María, se constata su aparición hacia el siglo VI a.C. (Ruiz Mata y González 1994: 223). Asimismo, este tipo de recipiente suele estar presente en todos los pequeños asentamientos de época tartésica de la campiña gaditana (Bueno Serrano 1998).

\section{d. Cerámica gris}

Entre los recipientes realizados a torno están también presentes las cerámicas grises orientalizantes que aparecen frecuentemente en todos los yacimientos del sur peninsular asociadas a las producciones orientales. Se trata de cerámicas que fueron creadas utilizando, como ya hemos dicho, el torno y hornos bien fabricados que permitían alcanzar elevadas temperaturas y atmósferas oxidantes cuya tecnología importaron los fenicios. Entre la cantidad de fragmentos recuperados y analizados de este tipo, exactamente unos 341, se observan al menos seis formas diferentes. La mayoría corresponden a formas abiertas, pero también las hay cerradas, aunque sean poco frecuentes en este tipo de cerámicas. El mayor número de fragmentos corresponden a cuencos simples con forma de casquete esférico (Fig. 19). Los hay de gran tamaño (30 cm de diámetro aproximadamente) y también de pequeño formato (16,5 cm) (Fig. 20; Lám. XI). La mayoría presentan el borde engrosado al interior y las superficies tratadas, bruñidas por ambos lados con una gran calidad, alcanzando alguno de ellos un brillo de aspecto casi metálico. Se han usado engobes para recubrir las superficies que posteriormente se han bruñido. Están también presentes algunos cuencos con las superficies sin tratar, borde engrosado y con el labio exterior plano. Hay también cuencos carenados de bordes rectos que presentan las superficies tratadas, bruñidas por el interior y el 


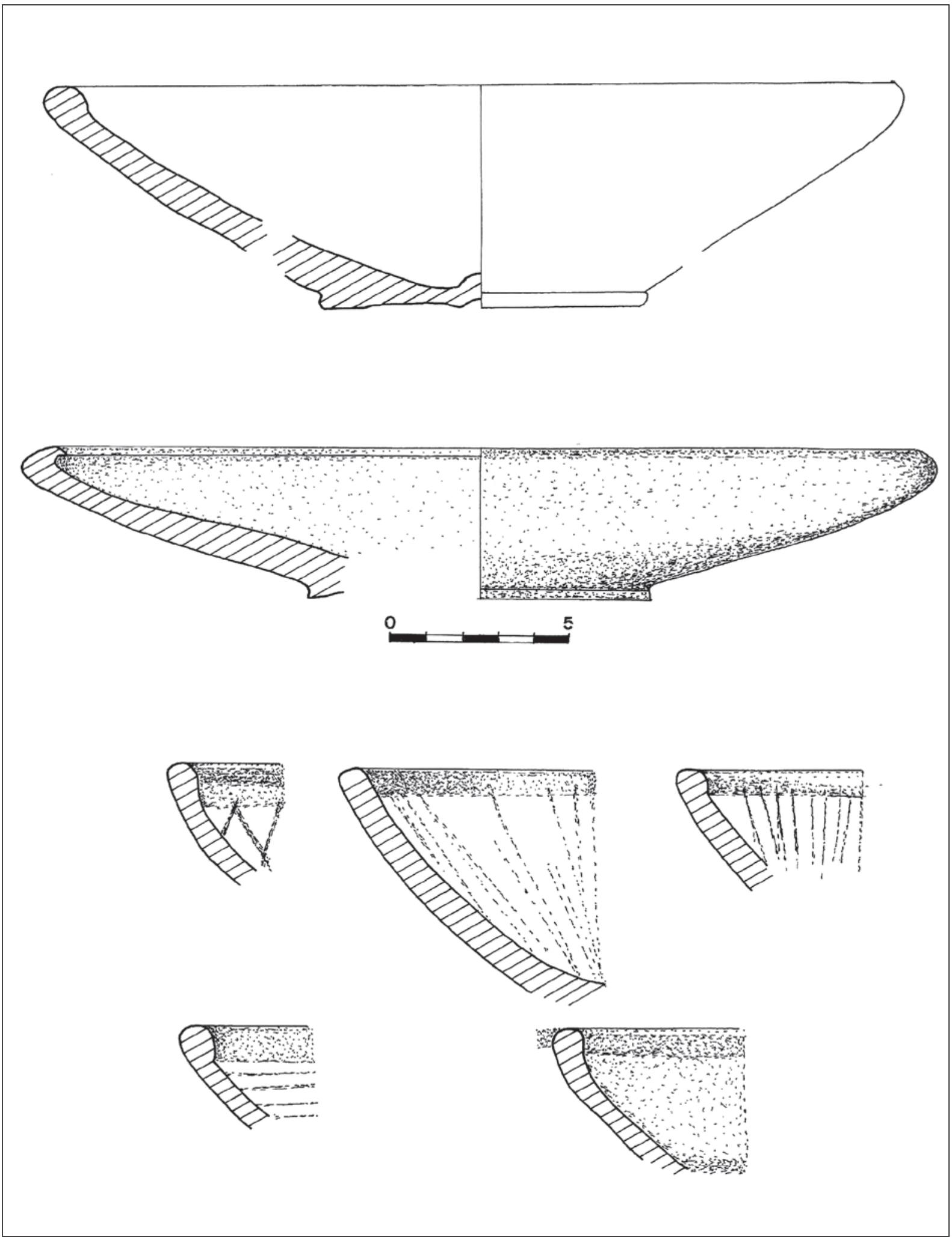

Figura 19. Cerámica gris 


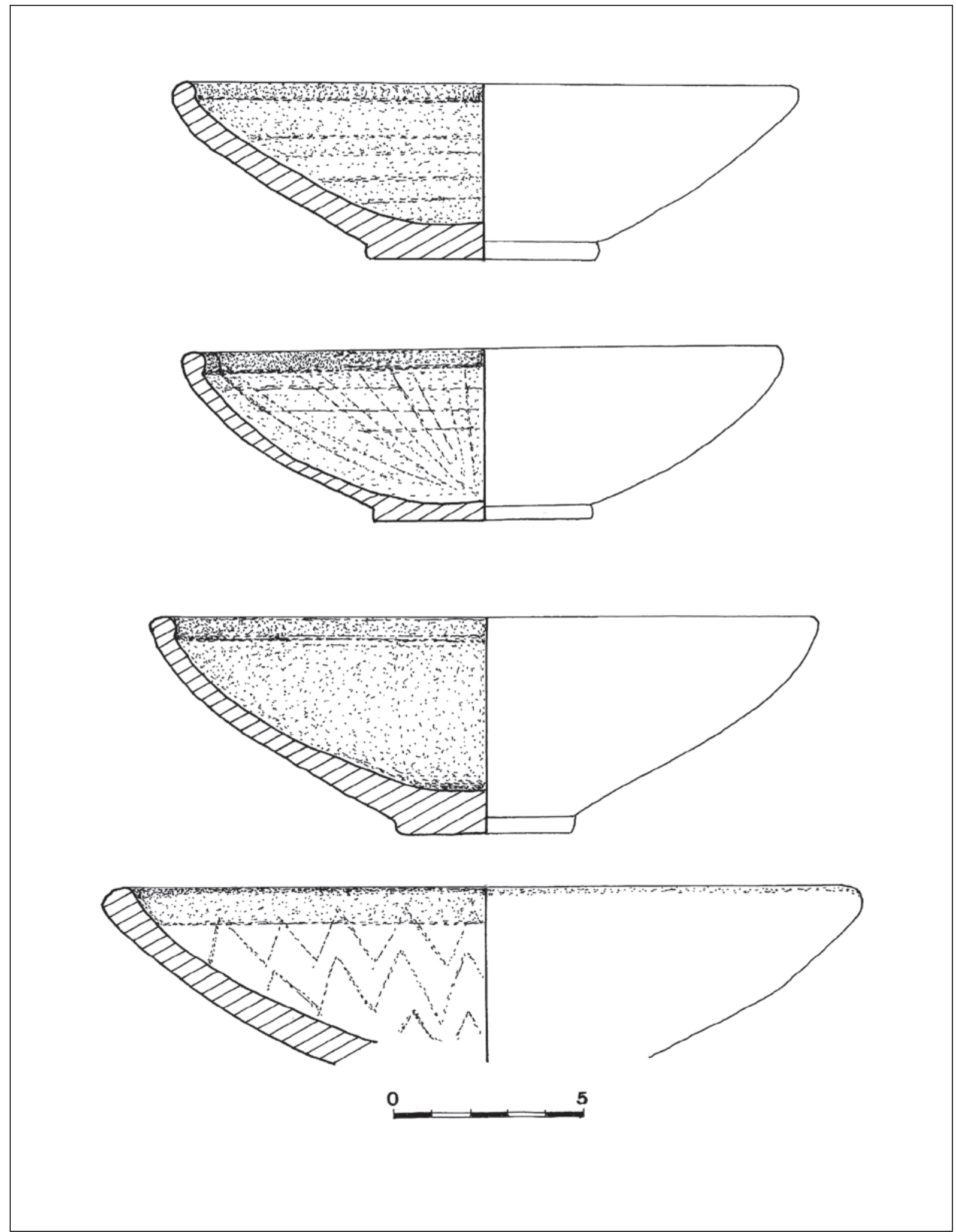

Figura 20. Cerámica gris 


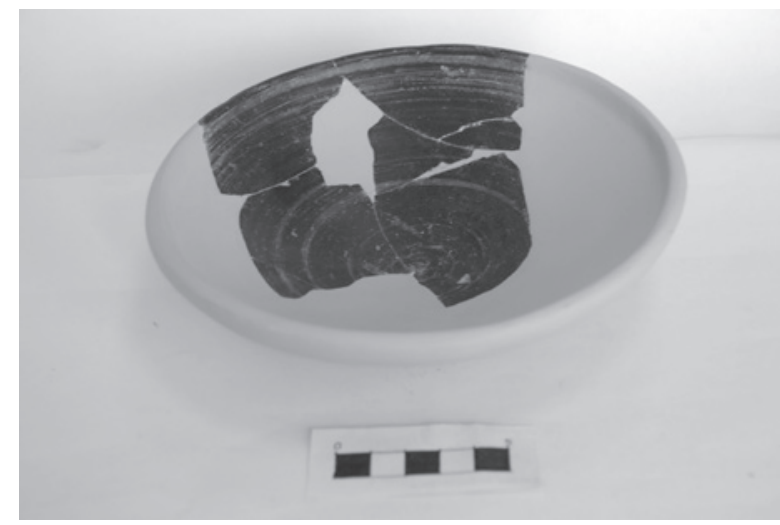

Lámina XI. Cuencos de cerámica gris

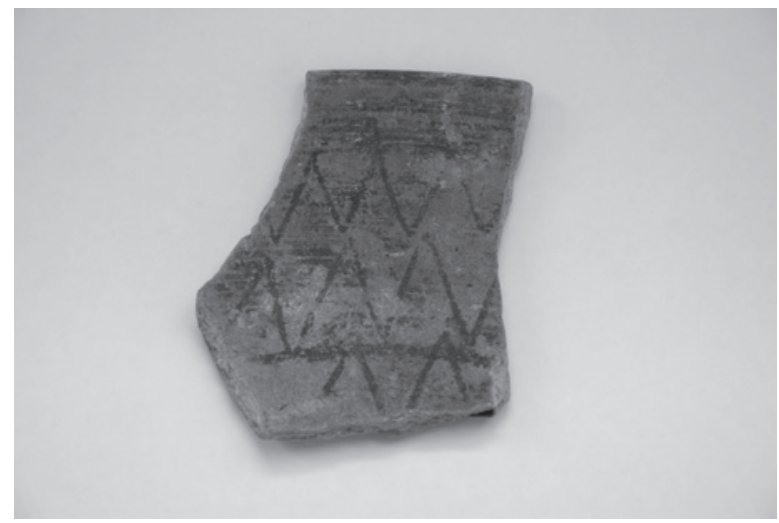

Lámina XII. Cerámica gris con decoración bruñida

exterior hasta la carena. Otra forma que aparece es la de grandes platos o fuentes con carena y borde saliente engrosado (Fig. 21: 7 y 8). Se trata de una forma también frecuente entre la cerámica gris orientalizante.

En cuanto al tipo de decoración que presenta este tipo de cerámica, podemos decir que se trata siempre de decoración bruñida, con motivos geométricos de trazos rectos, reticulados (Figs. 19 y 20), dientes de lobo (Fig. 20: 4) y en algunos casos, aparecen círculos concéntricos que siguen la dirección del torno y alterna franja bruñidas con otras sin bruñir (Lám. XII).

Menos frecuente entre los repertorios de cerámica gris del Sur de la Península, y más aún en ambientes domésticos, son las copas (Caro Bellido 1989 y Roos 1982), que suelen aparecer en necrópolis o en lugares identificados como santuarios. Éstas también están presentes en el Cerro del Castillo, a través de un ejemplar (Fig. 21: 1). Se trata de un recipiente abierto fabricado a torno en dos partes. Consta de un cuenco o plato de borde simple y un pié con forma de cilindro. Medidas: Diámetro máximo: $20 \mathrm{~cm}$ aproximadamente, altura del pie: $4,5 \mathrm{~cm}$, altura total: $8 \mathrm{~cm}$, diámetro exterior base: $9,2 \mathrm{~cm}$. Está realizada en pasta gris y presenta las superficies sin tratar. Los recipientes con los que presenta más afinidad este ejemplar del Castillo son los hallados en la excavación de Marqués de Saltillo, que se datan hacia el siglo VII a.C. (Belén y otros 1997: 166-169).

La quinta forma de vaso de cerámica gris que hemos podido identificar está representada por tres recipientes de cuerpo globular (Fig. 22: 1, 2, 3), que miden aproximadamente $13 \mathrm{~cm}$ de diámetro. Estas formas tampoco son frecuentes hasta ahora en el repertorio cerámico gris. Uno de ellos tiene con trazos bruñidos por el exterior.

Estas cerámicas están presentes desde mediados del siglo VIII a.C. en Doña Blanca (Vallejo Sánchez 1999: 87), pero se hacen más frecuentes en los siglos

siguientes, sobre todo en el VII y VI a.C., apareciendo con asiduidad en los asentamientos autóctonos de las campiñas gaditanas (Bueno Serrano 1998). En la costa malagueña, concretamente en el Cerro del Villar, este tipo de cerámica hace su aparición, aunque sea levemente, en el Estrato $5 \mathrm{del}$ Corte 5, que se fecha a mitad del siglo VII a.C., pero se hace más abundante en el Estrato IV del Corte 5, donde su proporción se hace digna de destacar por los excavadores, fechándose en el último cuarto del VII a.C. (Aubet y otros 1999: 90).

\section{e. Otros materiales hallados}

\section{Metales}

En el vertido exterior de la muralla se recogieron varias hojas de cuchillos afalcatados de hierro, similares a los que aparecen en el Túmulo 1 de las Cumbres, en el Castillo de Doña Blanca (El Puerto de Santa María, Cádiz), datado en el siglo VIII a.C. Éstos cuchillos aparecen formando parte del ajuar funerario en algunas incineraciones, junto a placas de cinturones y fíbulas de doble resorte (Ruiz Mata y Pérez 1995: 118). Las medidas que conservan los fragmentos hallados son aproximadamente de $10 \mathrm{~cm}$ de largo por 2,4 cm de ancho.

En superficie se recogió también un proyectil de plomo con forma de bellota. Este tipo de utensilio se utilizaba junto con la honda como arma arrojadiza. Los pueblos antiguos atribuyen a los fenicios la invención de la honda. El proyectil era colocado en una bolsa y se le daba un vigoroso impulso circular. Cuando el tirador soltaba una de las correas, el proyectil salía disparado a causa de la fuerza centrífuga. Los griegos y romanos utilizaron una honda con mango de madera. El 


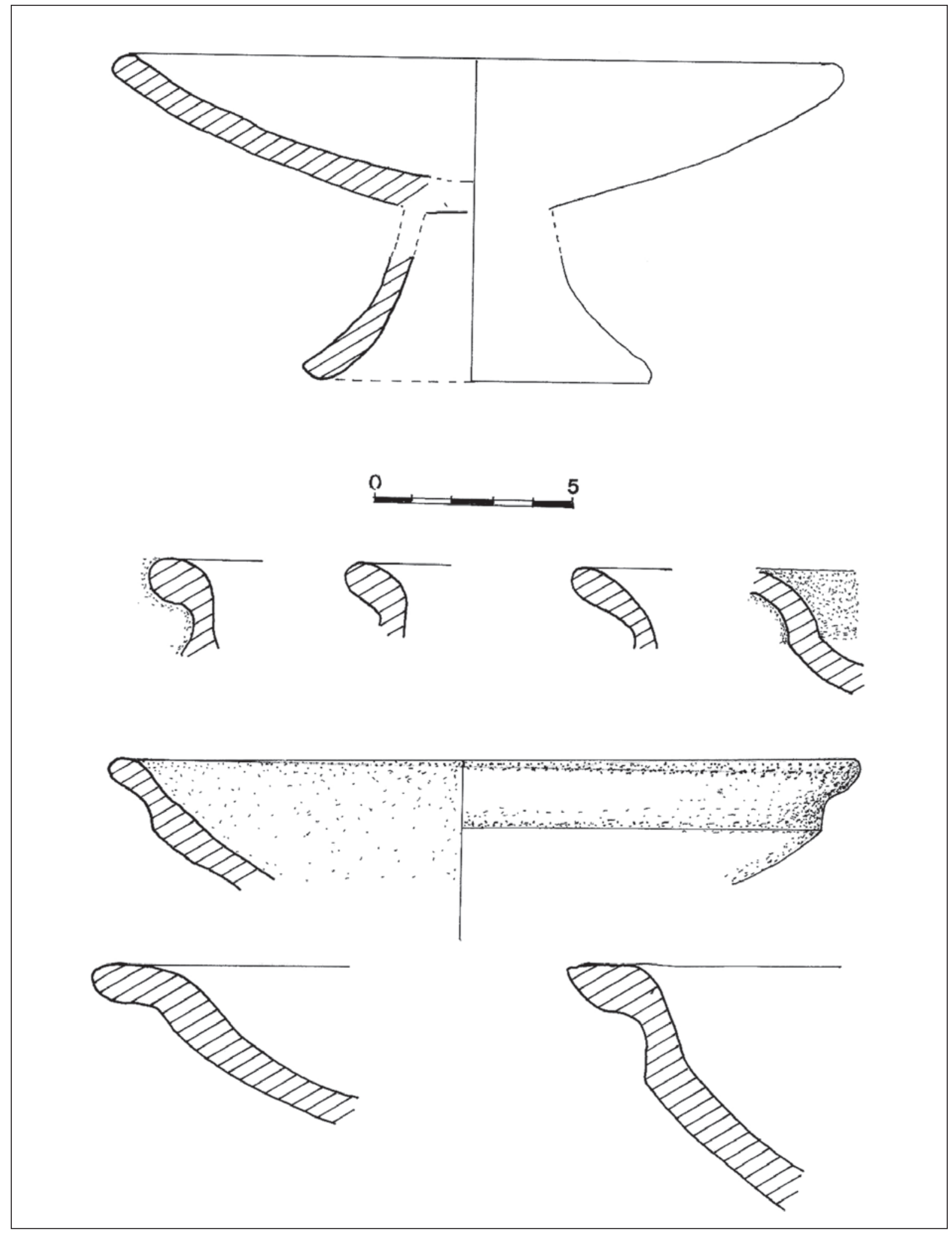

Figura 21. Grandes platos de cerámica gris 


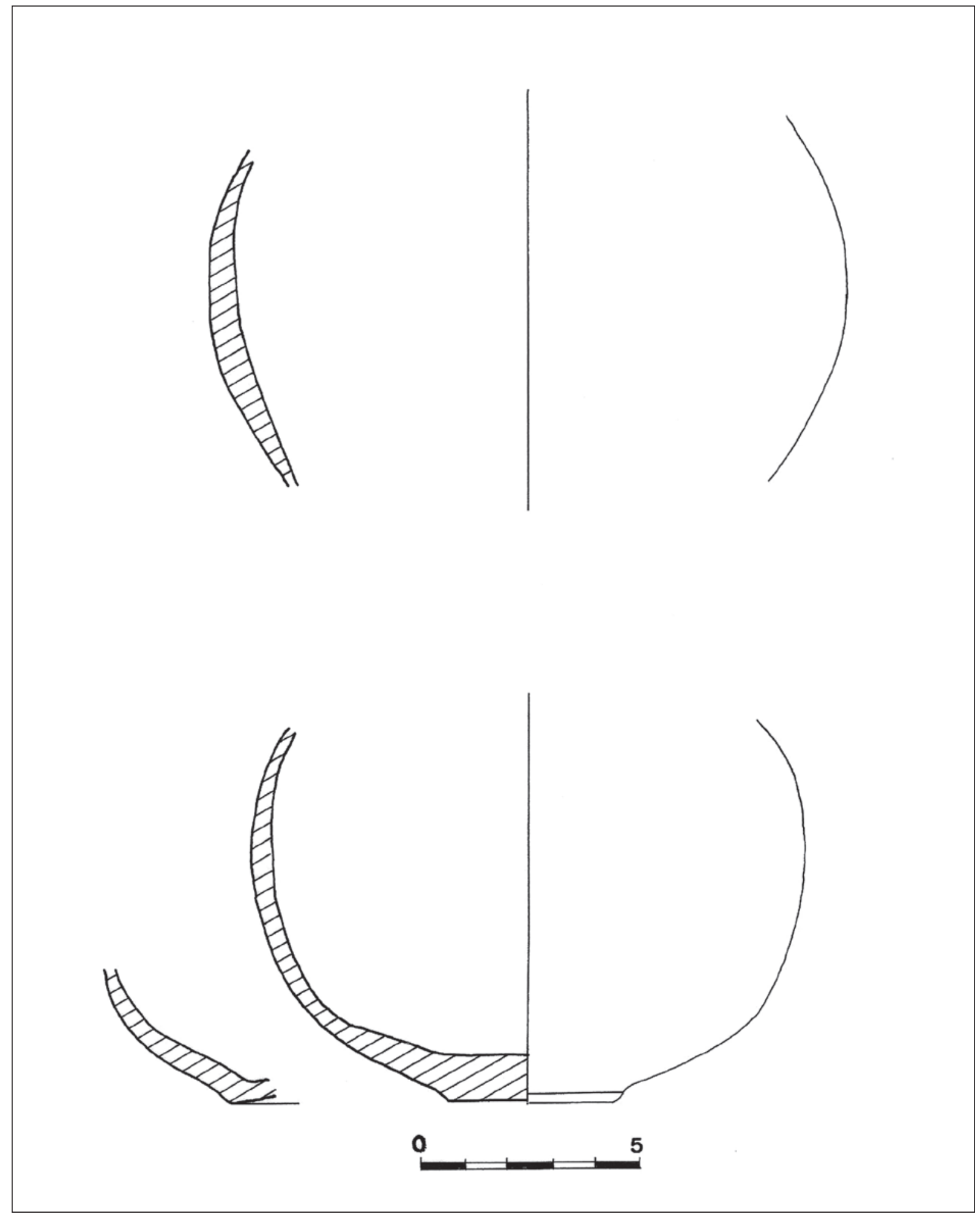

Figura 22. Cerámica gris: formas globulares 
hecho de que apareciera en superficie no nos permite atribuirlo a los fenicios porque también podría ser romano, pero es un dato importante a tener en cuenta.

Cuentas de collar

Se hallaron tres cuentas de collar de pasta vítrea, una mediana de color azul con orificio central de $1,5 \times 2 \mathrm{~cm}$ y dos cuentas minúsculas de $10 \mathrm{~mm}$, una de color rojo intenso y otra de color verde. A pesar de que su aparición es frecuente en los yacimientos fenicios y autóctonos del mediodía peninsular, el estudio del vidrio plantea dudas en muchos aspectos. En este tipo de material se realizan también escarabeos, amuletos, cuentas de collar y ungüentarios. Los elementos más antiguos son las cuentas de collar y los escarabeos, que se remontan al siglo VIII a.C., según los hallazgos del Túmulo 1 de la necrópolis de Las Cumbres y la sepultura número 20 del Cerro de San Cristóbal. Estas cuentas, que para algunos investigadores pudieron tener un valor mágico, se fabricaron siguiendo la técnica del núcleo de arena o enrollando hilos de vidrio en un alambre.

\section{Molinos de basalto negro}

Se trata varios fragmentos de piedras de moler fabricado en roca volcánica, concretamente en basalto negro, posiblemente procedente de Sicilia. El hecho de su posible procedencia del Mediterráneo, es lo que nos hace atribuirlos a la colonización fenicia.

\section{Malacología}

Entre los niveles arqueológicos que corresponden a la ocupación del asentamiento aparecen gran cantidad de restos malacológicos. Entre los ejemplares recuperados aparecen distintas especies: Phyllonotus trunculus (caracola), Ruditapes decussatus (almejas), Glicymeria pilosa (almeja redonda), Ostrea edulis (ostra), Tellina radiata (coquina).

Restos óseos faunísticos

Entre los restos óseos faunísticos recuperados en las proximidades del fogón y en el interior de alguna de las dependencias excavadas encontramos: Bos (bóvidos), Capra hircus/ovis (cabra y oveja) y Oristulagus cuniculus (conejo).
Ictiofauna

Se recogieron varias muestras que actualmente están siendo estudiadas.

\section{CONCLUSIONES}

El Cerro del Castillo (Chiclana, Cádiz) ha sido en el transcurrir de los siglos un enclave idóneo para la ocupación humana gracias a la magnífica ubicación que posee, en un lugar elevado, próximo a la costa y cerca de un río que fue navegable hasta hace unos años. Esta situación estratégica ha sido sin lugar a dudas el principal motivo de su ocupación desde época prehistórica hasta la actualidad.

Las investigaciones arqueológicas apuntan a la posible ocupación de éste desde el Bronce Final, ya que se conoce la existencia de núcleos de poblamiento, durante el Bronce Antiguo y Final en lugares colindantes, como en La Mesa (VVAA 1999) y en la Loma del Puerco, y en el mismo Cerro del Castillo.

En un momento mas avanzado, Bronce Final-Hierro I (siglo VIII-principios VII a.C.), se constata la existencia de un enclave construido a la manera oriental, con una muralla de casernas y pautas urbanísticas que permiten hablar de la existencia de una ciudad en el siglo VIII a.C. En el Cerro del Castillo, los fragmentos cerámicos de recipientes realizados tanto a mano, como a torno que aparecen entre los mampuestos de la muralla permiten adscribir esta fortificación a un momento muy concreto de la colonización fenicia. Se trata de un ejemplo más a incluir dentro del grupo de las murallas del área nuclear tartésica (Escacena y Fernández 2001: 109-127), junto a las de Doña Blanca (El Puerto de Santa María, Cádiz), Niebla (Huelva), Tejada la Vieja (Escacena del Campo, Huelva), La Papúa II (Zufre, Huelva), Lebrija (Sevilla), Cerro del Castillo (Aználcollar, Sevilla), etc.

En el siglo V a.C. el lugar continúa siendo ocupado; las construcciones se superponen, configurándose una ciudad sobre otra hasta la época romana. Hacia el siglo XIII sabemos que el cerro estaba ocupado por población almohade que reside en el lugar y que basa su economía fundamentalmente en la agricultura, de ahí el hallazgo de contenedores de grano para guardar los excedentes. En determinado momento, y ante la presión cristiana, el lugar se abandona, de ahí que en 1303 Fernando IV entregue la aldea yerma y vacía para su repoblación y defensa a Alonso Pérez de Guzmán. Es entonces cuando comienza a surgir el nuevo núcleo poblacional entorno a la colina donde, según el cronista 
de la Casa Ducal, se construyó el castillo o fortaleza del Iro. Muy cerca del Castillo se construyó la primera iglesia o convento de San Martín, que se convirtió en hospital, de ahí que muy cerca del mismo aprovechando las laderas del Cerro del Castillo surgiera el cementerio del Egido.

El emplazamiento de este asentamiento en la entrada de la bahía de Cádiz lo convierte en un enclave privilegiado y fundamental en las relaciones marítimas y comerciales con los navegantes venidos de Oriente. Desde el punto de vista militar, podemos decir que la fundación de diferentes enclaves en la Bahía de Cádiz responde a un modelo de actuación estratégica de todo un área con la intención de controlarla, donde la ciudadela de Chiclana actuaría como primer puesto de defensa contra el enemigo que quisiera entrar en la bahía. El asentamiento definitivo de fenicios en un contexto autóctono del Bronce Final se vio sin duda legitimado con la fundación del templo de Melkart, en el entorno de Sancti Petri.

Somos de la opinión de que el recinto fortificado y las diferentes dependencias excavadas están relacionados con el Heracleion. La magnitud e importancia del templo harían necesaria la existencia en un lugar próximo en tierra firme al amparo de temporales, donde residieran los encargados del templo (sacerdotes, astrónomos, siervos, etc.), así como, todos aquellos individuos relacionados con las transacciones comerciales y la vida cotidiana de cualquier comunidad (navegantes, comerciantes, artesanos, campesinos, etc.).

El análisis del repertorio arqueológico mueble recuperado en el interior de las dependencias, sobre todo el cerámico, nos sugiere una ocupación del cerro con carácter habitacional y doméstico en todos los periodos documentados; hasta el momento no podemos otorgar otra funcionalidad, como podría ser la de santuario o templo, aunque no descartamos que cuando se amplíe el área investigada se pueda apuntar además el uso religioso de este asentamiento. Los enseres y vajillas de uso doméstico adscribibles al Bronce Final-Hierro I son exactamente los mismos que los hallados en todos los yacimientos fenicios de las costas peninsulares, compartiendo especial semejanza con los hallados en el solar del Cine Cómico y Casa del Obispo en Cádiz, El Castillo de Doña Blanca en El Puerto de Santa María (Cádiz), con el Cerro del Villar en Málaga y Málaga capital. Los recipientes cerámicos fabricados a mano propios de la tradición del Suroeste peninsular se utilizan a la vez que los fabricados a torno de imitación oriental, aunque se aprecia una mayor presencia de los primeros en los niveles inferiores excavados y en la construcción de la muralla. Algunas formas son novedosas y no muy frecuentes en el repertorio fenicio peninsular, como las copas de cerámica gris o los oinocoes de este mismo tipo de cerámica, aunque se conozcan en algunos yacimientos del Bajo Guadalquivir, como en la Casa-Palacio de Marqués de Saltillo en Carmona (Belén Deamos y otros 1997). Otras formas reproducen los tipos fenicios pero presentan una factura muy tosca y mal ejecutada, como ocurre con los pithoi hallados junto a la muralla.

La mayoría de los recipientes de la fase orientalizante están realizados por alfareros locales con pastas también locales. La arcilla local contiene gran cantidad de yeso que hace que se formen protuberancias y pérdidas superficiales de material en las cerámicas una vez que se cuecen en el horno. Entre los contenedores las formas más abundantes son los píthoi y ánforas, lo cual evidencia la importancia del almacenamiento de productos, con seguridad líquidos, para el autoabastecimiento, para el transporte y para el comercio.

En época fenicio-púnica siguió existiendo en el cerro un importante asentamiento, con viviendas y dependencias muy bien construidas, con pavimentos perfectamente terminados, formados con arcilla apisonada con nódulos de barro u opus punicum. La amplitud de la ciudad rebasa el perímetro amurallado, construyendo la misma incluso sobre la muralla. En estos momentos, las formas cerámicas halladas son muy similares a las del alfar de Camposoto en San Fernando. Son numerosos los fragmentos de ánforas recuperados, como muestra de la importancia de los intercambios comerciales que se dieron en ese momento.

\section{BIBLIOGRAFÍA}

AUBET, Ma . E. (1994): Tiro y las colonias fenicias de Occidente. Ed. Crítica. Barcelona.

- (1999): Cerro del Villar I. El asentamiento fenicio en la desembocadura del río Guadalhorce y su interacción con el hinterland. Arqueología. Monografía. Junta de Andalucía.

BELÉN DEAMOS, Mª y otros (1997): Arqueología en Carmona (Sevilla): Excavaciones en la casa-palacio del Marqués de Saltillo. Colección Arqueología. Consejería de Cultura. Junta de Andalucía. Sevilla.

BELÉN, Ma . y PEREIRA, J. (1993): “Cerámica a torno con decoración pintada en Andalucía”, Huelva Arqueológica VII: 307-360.

BLÁZQUEZ, J. M. y otros (1970): “Las cerámicas del Cabezo de San Pedro", Huelva Arqueológica I. Huelva.

BIKAI, P. M. (1978a): The pottery of Tyre. Warmister. 
- (1978b): "The late phoenician pottery complex and chronology", BASOR 229: 47-56.

BUENO SERRANO, P. (1996): "Fenicios y tartesios, protagonistas de un acercamiento entre cultura", XXIV Congreso Nacional de Arqueología, vol. 3: 45-56. Valencia.

- (1998): El tránsito Bronce Final-Hierro en el entorno del Arroyo Salado (Bahía de Cádiz). Memoria de Licenciatura (inédita), Universidad de Sevilla.

- (2007): Informe Preliminar del Control Arqueológico de Movimiento de Tierra en Calle Santísima Trinidad. Chiclana (Cádiz). Memoria depositada en la Delegación de Cultura de la Junta de Andalucía en Cádiz.

BUENO SERRANO, P. y CERPA NIÑO, J. A. (2007): Actividad Arqueológica Preventiva en el Cerro del Castillo. Chiclana (Cádiz). Memoria depositada en la Delegación de Cultura de la Junta de Andalucía en Cádiz.

- (2007): Actividad Arqueológica Preventiva en la C/. Santísima Trinidad, Chiclana (Cádiz). Memoria depositada en la Delegación de Cultura de la Junta de Andalucía en Cádiz.

- (2007): Actividad Arqueológica Preventiva. Sondeo arqueológico en Colegio Público El Castillo. Chiclana (Cádiz). Memoria depositada en la Delegación de Cultura de la Junta de Andalucía en Cádiz.

- (2007): Actividad Arqueológica Preventiva en C/. Molino. Chiclana (Cádiz). Memoria depositada en la Delegación de Cultura de la Junta de Andalucía en Cádiz.

CARO BELLIDO, A. (1989): Cerámica gris a torno tartesia. Universidad de Cádiz.

CERPA NIÑO, J. A. y BUENO SERRANO, P. (2006): Actividad Arqueológica Preventiva en C/. CONVENTO $N^{\circ} 2$ Chiclana (Cádiz). Memoria depositada en la Delegación de Cultura de la Junta de Andalucía en Cádiz.

CERPA NIÑO, J. A. y BUENO SERRANO, P. (2007): Actividad Arqueológica Preventiva en la C/. CONVENTO $N^{\circ}$ 11-13 Chiclana (Cádiz). Memoria depositada en la Delegación de Cultura de la Junta de Andalucía en Cádiz.

ESCACENA, J. L. y FERNANDEZ, G. (2001): “Tartessos fortificado", Actas del Congreso Internacional de Fortificaciones en el entorno del Bajo Guadalquivir: 110-127. Alcalá de Guadaíra.

FERNÁNDEZ JURADO, J. (1990): “Excavaciones arqueológicas en el solar $n^{\circ} 29$ de la Calle Puerto de Huelva", Huelva Arqueológica XII: 11-69.
GONZÁLEZ RODRÍGUEZ, R. y otros (1993): “Paleogeografía humana del entorno noroccidental de Cádiz. Los procesos culturales desde el Neolítico a época medieval (1985-1992)", Investigaciones arqueológicas en Andalucía (1985-1992). Proyectos: 799-807. Huelva.

LADRÓN DE GUEVARA, I. (1994): Aportación al estudio de las cerámicas con impresiones digitales en Andalucía. Servicio de Publicaciones de la Universidad de Cádiz.

NEGUERUELA, I. (1983): "Jarros de boca de seta y de boca trilobulada de cerámica de engobe rojo en la Península Ibérica", Homenaje al Profesor Martín Almagro Basch, II: 259-279. Ministerio de Cultura. Madrid.

PELLICER, M.; ESCACENA, J. L. y BENDALA, M. (1983): El Cerro Macareno. EAE 124. Ministerio de Cultura. Madrid.

RAMÓN TORRES, J. (1995): Las ánforas fenicio-púnicas del Mediterráneo Central y Occidental. Universidad de Barcelona.

RAMÓN TORRES, J. y otros (2007): El taller alfarero tardoarcaico de Camposoto (San Fernando, Cádiz). Monografías. Junta de Andalucía. Sevilla.

RECIO, A. (1993): "Vestigios materiales cerámicos de ascendencia fenicio-púnica en la provincia de Málaga", Madrider Mitteilungen 34: 127-141.

ROOS, A. (1982): “Acerca de la antigua cerámica gris a torno en la Península Ibérica”, Ampurias 44: 43-70.

RUFETE, P. (1988-89): "Las cerámicas con engobe rojo de Huelva", en Fernández Jurado, J. (ed.), Tartesos y Huelva. Huelva Arqueológica X-XI, 3: 3-39.

RUIZ MATA, D. (1979): "El Bronce Final -Fase Inicial- en Andalucía Occidental. Ensayo de definición de sus cerámicas", Archivo Español de Arqueología 52: 3-18.

- (1985): "Las cerámicas fenicias del Castillo de Doña Blanca (El Puerto de Santa María”, Los fenicios en la Península Ibérica. Aula Orientalis III, 1-2: 241-263.

- (1992): "Sobre la época fenicia arcaica de Doña Blanca", Revista de Historia de El Puerto de Santa María 8: 9-44.

RUIZ MATA, D. y GONZÁLEZ, R. (1994): “Consideraciones sobre asentamientos rurales cerámicas orientalizantes en la campiña gaditana”, Spal 3: 209256. http://dx.doi.org/10.12795/spal.1994.i3.08

RUIZ MATA, D. y PÉREZ, C. (1995): El poblado fenicio del Castillo de Doña Blanca (El Puerto de Santa María (Cádiz). Ayuntamiento de El Puerto de Santa María. 
SCHUBART, H. (1976): "Westphönische Teller", Rivista di Studi Fenici IV, 2: 179-196. Roma.

- (1985): "Informe preliminar sobre la campaña de excavaciones de 1982 realizada en el asentamiento fenicio cerca de la desembocadura del río Algarrobo", Noticiario Arqueológico Hispánico 6: 177-217.
VALLEJO SÁNCHEZ, J. I. (1999): "Las decoraciones bruñidas en las cerámicas grises orientalizantes", Spal 8: 85-100. http://dx.doi.org/10.12795/spal.1999.i8.05 VVAA (1999): Excavaciones Arqueológicas en la Mesa (Chiclana de la Frontera, Cádiz). Aproximación al estudio del proceso histórico de su ocupación. Serie Monográfica Arqueología en Chiclana de la Frontera.

FeCha de ENTRADA: 16-08-2009 FeCHA DE ACEPTACIÓN: 18-01-2010 